\title{
Neandertal subsistence strategies during the Quina Mousterian at Roc de Marsal (France)
}

\section{Jean-Christophe Castel, Emmanuel Discamps, Marie-Cécile Soulier, Dennis Sandgathe, Harold L Dibble, Shannon JP McPherron, Paul Goldberg, Alain Turq}

\begin{abstract}
Recent excavations at the cave site of Roc de Marsal (in the Dordogne region of SW France) have yielded several Mousterian assemblages rich in well-preserved faunal remains. The Layer 4 faunal assemblage, associated with a rich Quina Mousterian occupation, provides an opportunity to investigate Neandertal prey selection, transport decisions and reindeer carcass processing strategies. One of the most striking characteristics of the Roc de Marsal Layer 4 faunal assemblage is an apparent lack of spongy parts that cannot be explained by taphonomic processes or carnivore activities. Limb elements were selectively transported to the site, where they underwent considerable further processing, resulting in a notably high degree of fragmentation of almost all elements. Comparison of reindeer carcass processing strategies employed by Neandertals during the Quina Mousterian with those identified for the later periods of the Upper Palaeolithic gives rise to some unexpected interpretations of Neandertal consumption behaviours. We show that this kind of intensive fragmentation is associated with bone grease rendering in ethnographic and Upper Palaeolithic contexts, in most such cases with the aid of fire. However, evidence of fire is remarkably scarce in Roc de Marsal Layer 4. Layer 4 could reflect a systematic Neandertal practice of sucking and chewing on the spongy portions of bones in order to extract as much of the highly nutritious bone grease as possible. Additionally, Roc de Marsal Layer 4 shows examples of use of animal resources for nonalimentary purposes by Neandertals. The abundance of cutmarks on the anterior surfaces of reindeer metapodials seems to indicate the acquisition of tendons, and bones were frequently used as retouchers.
\end{abstract}

\section{Keywords}

Mousterian, zooarchaeology, butchery processing, bone grease rendering, sinew extraction

\section{Introduction}


Among research on Neandertal behaviour, a prominent question has for long concerned the nature of their subsistence activities, specifically the manner in which they exploited prey species (e.g. Binford, 1984, 1989; Chase, 1989; Jaubert et al., 1990; Stiner, 1994; Gaudzinski 1995; Gaudzinski and Roebroeks, 2000; Speth and Tchernov 2001; Costamagno et al., 2006; Rendu et al., 2012). Moreover, how the subsistence strategies of Neandertals and modern humans might have differed remains a key issue. In this contribution, we discuss processing strategies of reindeer carcasses employed by Neandertals and modern humans in southwestern France, through the acquisition of new zooarchaeological data for the Mousterian site of Roc de Marsal and their comparison with data previously acquired for the Upper Palaeolithic. Roc de Marsal deposits include several levels associated with a Quina Mousterian lithic industry that delivered very well preserved faunal remains, heavily dominated by reindeer Rangifer tarandus. The richest of these is Layer 4. The large sample size and excellent preservation of the faunal remains from Layer 4 allows detailed investigation of Neandertal food acquisition and consumption behaviour.

\section{The Site of Roc de Marsal}

The cave of Roc de Marsal is situated in a low cliff along the upper edge of a dry tributary valley of the Vézère River, close to its confluence with the Dordogne River. It is a relatively small cave, but includes a flat terrace from which one has a clear view up and down the valley below (Fig. 1 and 2). The site was first excavated by Jean Lafille from 1953 until his death in 1971 and it is best known for the discovery of the remains of a Neandertal child in 1961 (Lafille, 1961; Bordes and Lafille, 1962; Turq, 1989; Sandgathe et al., 2011a).

More recently (2004 through 2010) excavations by a multi-disciplinary team have resulted in a new stratigraphic sequence, a better understanding of site formation processes, the discovery of large lithic and faunal assemblages, and a series of absolute dates (Guérin et al., 2012, this issue). Excavation methodology included 3D-point provenancing of all lithic and faunal items that were larger than $25 \mathrm{~mm}$, while smaller lithic and faunal items were recovered via wetscreening of the sediment through $5 \mathrm{~mm}$ and $2 \mathrm{~mm}$ meshes (for more details, see Dibble et al., 1995).

The deposits include 13 distinct strata (Table 1), although the basal strata (Layers 13 through 10) are either sterile or nearly so and the uppermost stratum (Layer 1) is of Holocene age. Layers 9 through 2 are Late Pleistocene in age and contain significant concentrations of Middle Palaeolithic lithic and faunal remains:

- Layers 9 through 7 are placed by recent TL dates around MIS 4 (Guérin et al., 2012, 
this issue). These layers yielded lithic assemblages dominated by high frequencies of Levallois components and lower frequencies of retouched pieces. Layer 7 also has an Asinipodian component (diminutive Levallois products first identified at Pech de l'Azé IV) (Bordes, 1975; Turq, 1979, 1980, 1985, 1988, 1992; Antignac, 1998; Thiébaut, 2003; Dibble and McPherron, 2006; Turq et al., 2008). Layers 9 and 7 are also notable for a significant number of very well preserved combustion features (Sandgathe et al., 2011b; Aldeias et al., 2012; Goldberg et al., 2013).

- Layers 6 and 5 are also associated with lithic industries that have a relatively high Levallois representation and relatively low frequencies of retouched pieces, but there is a clear trend towards reduced Levallois representation and increased frequency of retouching that continues into Layers 4,3 and 2.

- Layers 4 through 2 are associated with a lithic industry characterized by a low frequency of Levallois components and a high frequency of large, retouched scrapers that fit well with the traditional Quina Mousterian facies.

Layer 4 is the earliest of the three layers attributable to the Quina Mousterian. Recently obtained TL dates for this layer $(61.0 \pm 6.8 \mathrm{ka}, 53 \pm 4.1 \mathrm{ka}$ and $45.4 \pm 3.5 \mathrm{ka})$ place it at the end of MIS 4 or in the first half of MIS 3, probably around 50 ka (Guérin et al., 2012, this issue). Although densities of lithic artifacts are relatively high in Layers 4 and 3, they are lower than in Layers 9 through 5. Conversely, the density of faunal remains increases significantly in the top layers, especially in Layer 4 in which it reaches 12 plotted specimens per litre of sediment (although the density of faunal elements also reaches notably high levels in Layer 5: Table 1).

The medium and large faunal remains from Roc de Marsal have been the focus of several previous studies, notably by Castel (2004, 2010a; Castel et al., 2007), Soulier (2007) and Hodgkins (2012). From level 2 to 5 the faunal material presents similar characteristics, with evidence of a primarily anthropogenic associations and limited post-depositional modifications. In the lower levels, the assemblages are dominated by red deer and roe deer, with low frequencies of reindeer and horse. The upper part of the sequence is strongly dominated by reindeer (Fig. 3a and b). Horse is the second most frequent species, while bison, red deer and roe deer are rare. In this paper, we focus on the analysis of the richest of these top layers - Layer 4 - attributed to the Quina Mousterian.

\section{Material and methods}


Layer 4 contains a very large faunal assemblage, with more than 23,000 remains. Only part of it has yet been examined. Material from five squares distributed in different parts of the excavated area has been examined (see figure 2), including both the plotted remains (i.e., those greater than $25 \mathrm{~mm}$ in maximum dimension) and smaller finds collected from the screens (Table 2). This sample includes 4780 faunal remains, representing about $20 \%$ of the total Layer 4 faunal assemblage. Comparison between squares indicates that Layer 4 fauna is very similar throughout its extent in terms of species composition, bone preservation, bone fragmentation, frequency and degree of combustion, frequency of cutmarks and number of retouchers. Consequently, we performed additional detailed analyses on only the three richest squares (G18, K16 and Q17; NISP=3410). The results presented below concern observations made on the material from these three "fully analysed" squares, which we consider representative of the Layer 4 fauna.

The faunal material is heavily fragmented and consists primarily of long bone shaft fragments. For the fully analysed squares (G18, K16 and Q17), the outer surface of 3035 fragments measuring more than $30 \mathrm{~mm}$ in maximum dimension have been examined with hand lens in order to document both geogenic (taphonomic alterations of the cortical surfaces) and anthropogenic modifications (mainly percussion marks, cutmarks or combustion). Teeth and bones measuring less than $30 \mathrm{~mm}$ in maximum dimension (NISP=86 and 212 respectively) were examined more summarily, and 77 specimens were considered too heavily broken to be examined. In addition, we classified and counted unidentified bone specimens recovered from screens (NISP=19,631) by bone tissue type (compact, spongy, rib-like) and combustion degree (brown, black, grey or white).

For reindeer teeth, age of death was estimated using age classes from Bouchud (1966). Mandibles with at least three teeth left in place, as well as isolated inferior DP4 and M3 teeth were separated in three groups: juvenile, adult and old. Mortality profiles based on these broad age groups are then discussed using adjusted ternary diagrams (Discamps and Costamagno, 2015). Skeletal-part profiles are analysed by comparing minimum number of individuals and animal units (MNI and MAU, respectively) values (Binford, 1978) with bone density (Lam et al., 1999) and Unsaturated Marrow Index (Morin, 2007). For long bone shafts, the minimum number of elements (MNE) is based on the count of foramina and landmarks. For metapodial shafts, MNE values are calculated by dividing the cumulative length of the anterior groove of each fragment by the mean groove length of complete 
metapodials of adult reindeer $(140 \mathrm{~mm}$ for metacarpal and $226 \mathrm{~mm}$ for metatarsal, for calculation and biases see Castel, 1999, 2005, 2010b; Morin, 2004). For reindeer ribs, MNE calculation is based on the same principle, using the cumulative length of fragments with more than half of their circumference, and a mean value of $7000 \mathrm{~mm}$ of ribs per individual (Castel, 2005, 2010b). Fracture outline is analysed following Villa and Mahieu (1991). Cutmark percentages by element are calculated by dividing the number of fragments with at least one cutmark by the total number of identified fragments for the skeletal part concerned with an observable surface.

\section{General characteristics of the Layer 4 Fauna}

\subsection{Bone preservation and material characteristics}

Root marks and concretions are the most common traces observed (11\% and $13 \%$ of the remains, respectively). In more than $90 \%$ of the cases, bones were affected on less than $25 \%$ of their cortical surfaces. Other superficial traces, such as a partial dissolution, mechanical erosion, trampling marks, exfoliation or digestion are exceptionally rare (less than 1\%). Of the 3035 bones examined, only 38 (1.3\%) show gnaw marks. These are generally located on shafts and are not very extensive. They are probably the by-product of scavenging by a foxsized predator, but could possibly even be the result of human consumption. Thus, the assemblage has not been significantly modified by carnivores.

Because the material is heavily fragmented, a substantial proportion of the bones could not be identified, thus biasing the analyses (Fig. 4). On the other hand, this situation is commonly the case in Upper Palaeolithic sites (as shown for example in southwestern France by Castel, 1999; Costamagno, 1999; Morin, 2004; Soulier, 2013 and others), with which the data is compared.

Spongy bone is under-represented but its proportion increases among fragments of smaller size (Fig. 5). Part of the spongy bone was reduced to fragments so small that they would have become analytically "invisible" if screen refuse had not been studied.

Burned specimens are particularly rare; they represent only $1.2 \%$ of all the collected material (Table 3). This fits well with the scarcity of heated flints and the apparent lack of combustion features in Layer 4 (see Sandgathe et al., 2011b; Aldeias et al., 2012; Goldberg et al., 2012). These small burned bones might have resulted from a very occasional use of fire. 


\subsection{Species representation}

Reindeer is by far the dominant species in Layer 4 (NISP=1082, \%NISP=82.5\%; Fig. 3b). Red deer, the main taxon with which reindeer bone fragments may be mistaken, is represented by only 9 specimens. As Layer 4 does not contain other mammal specimens belonging to the same size class, it is very likely that most of the 2561 specimens attributed to 'reindeer-sized mammals' belong to reindeer (Table 2). Reindeer remains would thus represent approximately $78 \%$ of the assemblage, with approximately $21 \%$ represented by larger ungulates (mainly horse and bison) and the remaining $1 \%$ represented by small mammals and carnivores. Because of the low abundance of other taxa, we only present detailed analyses of reindeer exploitation strategies.

\section{Reindeer exploitation}

\subsection{Selection of hunted reindeer}

For the fully analysed squares, a reindeer MNI of 12 is given by the tibia (MAU of 11.5). Our sample represents only about $14.8 \%$ of the Layer 4 fauna collected during recent excavations (3,410 of 23,094 remains), thus we can estimate the total number of reindeer in the modern excavations to 78 individuals. Considering that the modern excavated area is about one third of the whole site, the potential total number of reindeer introduced and preserved in Layer 4 would have been around 230 individuals.

Teeth remains from Layer 4 are few and often fragmentary. Age of death was estimated for nine mandibles and four isolated teeth (lower DP4 and M3). All age categories are present, but the juveniles are the least abundant ( $\mathrm{MNI}=3$ juveniles, 6 adults, 1 old individual: Fig. 6 ). Deciduous teeth are not particularly abundant among the small fragments and are difficult to identify anatomically. Small sample size makes interpretation of the mortality profile difficult, as shown by the large confidence ellipse in Fig. 6. However, the mortality pattern most likely corresponds either to the living population (thus potentially indicating hunting episodes without selection) or to a prime-age dominated assemblage (in which case it could indicate preferential hunts favouring adult individuals).

Foetal bones are present in small quantities in Layer $4(\mathrm{NISP}=19)$, and most are of reindeer (Fig. 7). Other foetal bones, more fragmented, were not identified to species but are probably also reindeer. Those definitely attributed to reindeer correspond to a minimum of four 
individuals and indicate that females have been killed. According to Spiess' (1979) tables, their stage of growth suggests that the hunting period occurred from the end of the winter to the mid-spring. Additionally, reindeer teeth indicate that two individuals were hunted during summer and fall.

\subsection{Skeletal-part profiles}

Long bone shafts are the most abundant elements (Fig. 8) and represent $72 \%$ of the assemblage. Other parts of the skeleton are rare, except teeth, without any disparity between elements or skeletal regions.

Tibia and metatarsus seem to be better represented than other long bones in both NISP and MAU counts (Fig. $8 \mathrm{a}$ and b). We assume that this is due to the fact that their fragments are more easily identifiable. Anterior grooves of metapodials can be easily identified on fragments about $1 \mathrm{~cm}$ long. Angulations on tibia shafts are also easy to identify. On the other hand, given the fragmented nature of the faunal assemblage, humerus and femur foramina were more difficult to distinguish (e.g. on shafts less than $30 \mathrm{~mm}$ long). Furthermore, radius fragments smaller than $50 \mathrm{~mm}$ show few identifiable landmarks or conformation, except the foramina itself. Conversely, tibia foramina remain identifiable for very small fragments. We consider that given the NISP and MAU values, there is no strong evidence that the long bones were brought back to the site in variable frequencies.

Cranial, mandible and vertebral fragments are rare (NISP of 29, 43 and 21, respectively). Several portions of the cranium are present (maxillary, petrous bone, occipital condyles), as well as fragments of all the different types of vertebrae (Fig. 8 a and c).

Rib fragments are more abundant (NISP=117), but of small size, for an estimated MNI of only one individual (cumulative length of $5092 \mathrm{~mm}$, cf. section 3 for calculation details). Most carpal and tarsal bones are absent, notably the talus despite its high density and the fact that it is easily identifiable even when highly fragmented (see Castel 1999 or 2010b: 545). The calcaneum is present but reduced to small fragments (NISP=9; MAU=4). The patella, with 4 fragments, is noticeably more abundant than the distal femur or the proximal tibia. Vestigial phalanges and metacarpals are very rare. Phalanges are also rare, especially the 
distal one (NISP=2). Proximal phalanges are mainly represented by their distal articulations $(\mathrm{NISP}=15$ out of 17$)$.

\subsection{Reindeer skeletal representation}

MAU values (Fig. 9) and the similar abundance of metapodials and other long bones (as discussed above) may indicate the transportation of complete limbs to the site. Articular ends of long bones as well as most carpals and tarsals are very rare. This differential destruction of limb parts must have logically occurred at the site after complete limbs where brought back. The higher frequency of patellas, compared to distal femur and proximal tibia, as well as the high frequency of calcaneus compared to that of talus and distal tibia, further support this hypothesis. An alternative scenario would be that some long bone shafts had been brought to the site for the exclusive aim of being worked as retouchers, but this must have been a marginal phenomenon. We thus strongly suspect that the almost complete destruction of articular portions occurred on site, during or after the butchery processes.

Foetus bones are quite abundant in Layer 4 and gravid reindeer females ordinarily have antlers (e.g., Murray, 1993). Reindeer antler is rare at Roc de Marsal in spite of good overall faunal preservation, although some relatively large specimens (over $30 \mathrm{~cm}$ ) have been recovered. This scarcity may result from the antlers having been left at the kill site. Crania and mandibles are rare, even their densest parts (e.g. teeth or temporal). These parts might not have been systematically brought back to the site. The scarcity of phalanges, which are very fragmented, might also be indicative of their abandonment at the kill site or a particular treatment in situ. The distal parts of proximal phalanges have higher frequencies than the proximal parts or the distal metapodials. This pattern could be explained by systematic breakage around the metapodial-phalange articulation and subsequent use of the different parts separately (this hypothesis, however, needs to be tested with bigger sample sizes). Vertebrae are present in much lower frequencies (NISP=22) compared to ribs (NISP=117). The same is true for vertebral bodies that are less abundant (NISP $=1+2$ unfused discs) than the neural arches and their different non-articular processes (NISP=19). A systematic destruction of the vertebral bodies after being brought to the site appears to be the most likely explanation, though selective transport of the postcranial axial skeleton cannot be totally ruled out. 
The under-representation of the axial skeleton is commonly considered as evidence of selective transport, with introduction to the site of limbs alone. Marean and Frey (1997) and others have highlighted the difficulty of interpreting the under-representation of the axial skeleton. At Roc de Marsal, several lines of evidence give us the opportunity to discuss the relative scarcity of axial skeleton components (Figs. 8 and 9):

- Long bone articulations are systematically far less abundant than their shafts. They form $3.4 \%$ of the total of identified long bones. The same is true for ribs.

- High or low-density articular ends are equally underrepresented.

- High-density limb bones, such as some carpals and tarsals, are also rare or missing (e.g. talus); the petrous part of the temporal bone is surprisingly under-represented based on observations from similar sites; mandibular teeth and bones (mainly fragments of the body of the mandible) are more abundant than upper teeth and cranial bones; both mandibular and occipital condyles are missing.

- Low-density bones are not represented in equal proportions: there are a significant number of foetal bones, patellas and vertebral neural arches, but vertebral bodies are almost completely absent.

The skeletal-part profile cannot be entirely explained by post-depositional destruction of lowdensity elements (correlation between density and MAU is quite low and not statistically significant; $r s=0.22 ; \mathrm{p}>0.05)$. The highly statistically significant $(\mathrm{rs}=0.959 ; \mathrm{p}<0.001)$ correlation between the UMI marrow index and the MAU (Fig. 10) suggests a preferential introduction of bones rich in marrow. Axial skeleton may have often been left at the kill site. But transport decisions cannot alone explain the variations observed in the representation of both axial elements and articular portions of the limbs. Consequently, an additional processposterior to transport - is required in order to understand the low representation of these spongy portions.

It is not possible to determine whether the foetuses were brought to the cave separately (after evisceration at the kill site) or inside the bodies of transported females. In the latter scenario, the observations made above suggest that ribs and vertebra would have been subsequently destroyed on site at Roc de Marsal. 


\subsection{Carcass processing}

Despite high frequencies of anthropogenic marks (Table 4), the different carcass processing stages cannot be equally documented at Roc de Marsal. Evisceration was not identified, probably due to the rarity of the axial skeleton. Similarly, the scarcity of articular portions hinders discussion of the different stages of disarticulation. At Roc de Marsal cutmarks are abundant $(20.3 \%)$ on meat-bearing elements and mostly correspond to defleshing. Cutmarks are also very abundant on metapodials (Table 4). According to experiments by Thiébaut et al. (2011), some marks recorded on the lateral and medial parts of these bones at Roc de Marsal could correspond to skinning, while others seem to indicate sinew removal (Thiébaut et al. 2011; Costamagno, 2012; Soulier, 2013). Two types of cutmarks were observed on the anterior side of the metapodials (Fig. 11): short transverse or oblique marks on both sides of the groove that correspond to sinew severing, and longitudinal marks resulting from the passage of a flint edge under the sinew to separate the latter from the bone.

Comparison with other sites is rendered difficult by the lack of published detailed analyses of cutmark locations for Middle Palaeolithic sites (as has been done for Upper Palaeolithic sites by, for example, Delpech and Villa, 1993; Castel, 1999; Costamagno, 1999; Soulier, 2013). In order to assess the Roc de Marsal pattern, we compared it with our own data (mainly unpublished) from different Upper Palaeolithic sites from southwestern France (Fig. 13). The frequencies of defleshing cutmarks on shafts at Roc de Marsal and other sites appear very similar for radio-ulna or tibia. However, an over representation of cutmarks on the anterior side of the metapodials is evident at Roc de Marsal. This has been observed in the Aurignacian assemblage of Castanet (Castel, 2011), but to a lesser extent than what is documented at Roc de Marsal. According to their location, these cutmarks do not relate to the removal of skin or flesh but rather to the severing of the extensor sinew (cf. Thiébaut et al., 2011; Costamagno, 2012; Soulier, 2013). These sinews are smaller than those on the posterior side and more difficult to remove without leaving cutmarks (cf. Binford, 1981). This action is observed more frequently on the metacarpal than on the metatarsal. The high frequencies of cutmarks on the anterior side of metapodials seems to be an original characteristic of the Quina Mousterian of Roc de Marsal.

The breakage of long bones, presumably for accessing marrow, is evidenced by the analysis of fracture patterns. All long bones are broken and show typical fresh-bone fracture patterns (smooth surfaces and oblique angles). Percussion notches are abundant as they occur on 19.7 $\%$ of the marrow-bearing bones (Hodgkins, 2012). As one would expect as a result of 
identification biases (Castel, 2005), they are preferentially located around foramina. The abundance of shafts and the lack of articular regions (including high density bones) could indicate a systematic breakage around articulations instead of classical disarticulation with sharp flints that was observed for the Upper Palaeolithic site of Cuzoul de Vers (Castel 1999, 2003, 2010b, 2012).

Lastly, evidence of technical exploitation of the bones is present in Layer 4. Retouchers are frequent on reindeer and horse long bone shafts (NISP=115): they are present on about $4.5 \%$ of long-bone shaft fragments, or more than $20 \%$ if only large $(>70 \mathrm{~mm})$ fragments are considered. Their numeric abundance highlights the multi-purpose utilization of prey by Neanderthals.

\section{Discussion}

\subsection{Prey selection}

As evident in many other Quina assemblages from the Périgord and Charentes regions of southwestern France (Laquay, 1981; Guadelli, 1987; Delpech, 1996; Beauval in Airvaux, 2004; Costamagno et al., 2006; Niven et al., 2012; for a review see Discamps et al., 2011 and Discamps and Royer, this issue), reindeer was the main prey of Quina hunters at Roc de Marsal, while horse, bison and red deer are frequently present in small proportions. The abundance of reindeer in the assemblage could reflect selective hunting and/or environmental constraints (Costamagno et al., 2006; Discamps et al., 2011; Rendu et al., 2012).

Correlations between changes in herbivore communities and palaeoenvironmental proxies (Discamps et al., 2011; Guérin et al., 2012; Morin et al., 2014; Discamps and Royer, this issue) tend to place the Quina Mousterian at the end of MIS 4, around Heinrich Stadial 6, when southwestern France was characterized by harsh conditions and low ungulate biomass (Discamps, 2011, 2014), comparable in some ways to modern tundra conditions (SánchezGoñi et al., 2008; Fletcher et al., 2010; Discamps et al., 2011). However, the absolute dates recently obtained at Roc de Marsal contradict this chronological positioning (Guérin et al., this issue). In any case, a significant decrease in the availability of prey species at the Quina could help explain such intensive subsistence behaviour on the part of Neandertals.

Unlike what is possible for the Upper Palaeolithic (Castel et al., 2008; Castel et al., 2014), the relatively coarse chronological resolution of the available absolute dates for this time period, 
and the scarcity of contemporaneous paleontological assemblages, does not allow adequate discussion of the complex interplay between prey selection and environmental constraints (Discamps et Royer, this issue). The predominance of reindeer in Layer 4 could be a reflection of hunting strategies that still remain to be more fully researched, as this specialization on reindeer may reflect a preferential selection of prey rather than simple availability.

\subsection{Selection of parts of reindeer carcasses for specific purposes}

The Level 4 faunal assemblage has some original characteristics that distinguish it from the other layers at Roc de Marsal (work under progress; Castel, 2004, 2010a; Castel et al., 2007; Soulier, 2007; Hodgkins, 2012): articular regions and especially spongy bones seem to have been systematically destroyed on site. Because these characteristics do not appear to result from taphonomic biases, we can explore different potential behavioural explanations for these faunal patterns and compare them with what is known for Middle and Upper Palaeolithic populations in other Western Europe sites.

The skeletal-part profile observed for Layer 4 strongly resembles some of those from Upper Palaeolithic sites known for their intensive combustion of spongy bone. One might have expected a similar activity at Roc de Marsal were it not for the lack of evidence of fire in Layer 4. In order to further examine the intense bone fragmentation at Roc de Marsal, we compared our data to those collected from the late Upper Palaeolithic site of Cuzoul de Vers (Castel, 1999, 2003, 2010b and 2012). This site is remarkable for its high proportion of identified burned bones (15\% of NISP; Villa et al., 2002; Costamagno et al., 2009; Théry et al., 2009). In Cuzoul de Vers, after complete meat removal, limb bones were systematically broken in order to extract the marrow as well as to separate complete articular joints (with compact and spongy bone together) from shafts. At the same time, transversal and spinous processes of vertebrae, as well as the body of the ribs, were separated (leaving the articular ends of ribs with the body of the vertebrae) (Fig. 14). The burned part of the spine and ribs thus includes the entirety of the vertebral bodies and the rib ends, in addition to the cranial base (the occipital condyle and the petrous part) (Castel, 2003). The nature of the destruction can be corroborated by examining smaller fragments (Castel, 1999; Outram, 1999): a large number of unidentified small spongy fragments are present, attesting to the destruction of articular portions and axial bones at the site.

When burned bones are removed from the Cuzoul de Vers assemblage, its similarity with Roc de Marsal appears to be very strong ( $r=0.99$; $r s=0.85 ; \mathrm{p}<0.001$ for both). A question thus 
emerges: apart from burning, what kind of human processing of skeletal remains could explain the over-representation of shafts and the under-representation of articular ends, whether of low or high density?

Concerning the intentional breakage of bones for marrow, we have observed that it produced smaller fragments than are documented in well preserved Upper Palaeolithic assemblages dominated by reindeer: long bone fragments over $8 \mathrm{~cm}$ are less abundant (Fig. 15). This is not due to reindeer bone characteristics, but may result from differences in breakage patterns. The reasons are not yet clear, but it potentially supports a bone grease rendering hypothesis. Intentional breakage of the first phalanges appears to be systematic (12 out of 13). The sample is unfortunately too small to determine whether the second phalanges were also broken systematically or not.

\subsection{Grease extraction}

In the last decade, the idea that bone grease rendering was a part of hominin subsistence behaviour has been debated for Middle and Upper Palaeolithic sites. In general, marrow and bone grease exploitation seems to be very common among hunter-gatherers (Outram 2001) (e.g., Hadza: Bunn et al., 1988; O'Connell et al., 1988; Nunamiut: Binford, 1978; Siberian groups: Potapov 1964; San groups of the Kalahari: Yellen 1991; Kent 1993; and the Alyawara of Central Australia: O'Connell and Marshall, 1989). As Costamagno (2013: 209) states: "bone grease rendering was commonly practiced by forager groups living in very diverse environments" (cold tundra, boreal forest, plains, high desert, etc.) (Denys, 1672; Leechman, 1951; Vehik, 1977; Binford, 1978; Gronnow et al., 1983; Brink, 1997; Morrison, 1998; Abe, 2005; Saint-Germain, 2005; Costamagno and David, 2009; Costamagno and Rigaud, 2014; Karr et al., 2015). However, this food preparation technique is not universally observed among modern hunter-gatherers (e.g. Hadza: Bunn et al., 1988; O'connell et al., 1988; Dassanetch: Gifford-Gonzalez, 1989).

Studies on bone grease rendering typically postulate that fire is involved in the process. Spongy bones are broken up and then boiled in water (cf. Leechman, 1951; Manne et al., 2006; Costamagno and Rigaud, 2014). Large, pitted stone anvils, along with heat-fractured and heat-scarred stones, are considered to be typical archaeological indications of grease rendering activities (Vehik, 1977; Stiner, 2003; Manne et al., 2006). According to Church and Lyman (2003), systematic crushing of bones does not play a major role in grease exploitation 
techniques. Nonetheless, other authors have argued that bone fragmentation facilitates the gathering of grease (Costamagno, 2013; Janzen et al., 2015) and that extensive crushing of the spongy components of bones is a necessary step to access bone grease efficiently (e.g., Outram, 2003; Karr et al., 2015).

In parallel, Schaefer and Steckle (1980) observed that, in the past, the Inuit of Quebec were consuming the spongy part of mammal skeletons by simply chewing the bones, and Binford (1981: 148) also described the Nunamiut practice of gnawing on reindeer bones. This concerned mainly ribs, but also to some extent dorsal spines of thoracic vertebrae, the proximal margin of scapula and soft bones from young individuals. Oliver (1993) notes a similar practice among the Hadza people. It is thus possible that the spongy bones from Roc de Marsal were eaten and destroyed or boiled in perishable containers. In both cases, a preliminary breakage facilitates the process.

Recently excavated Mousterian sites provide interesting points of comparison for interpretation of the assemblage of Layer 4 of Roc de Marsal. The analysis of the Mousterian site of Noisetier Cave in the French Pyrenees (Costamagno, 2013) highlights differences in the processing of chamois and red deer carcasses: spongy bones are abundant for chamois, primarily accumulated by non-human predators, while red deer remains, accumulated by humans, are mostly shaft fragments. Burned bones are present but not abundant and this under-representation of spongy portions has been interpreted as evidence of a bone grease rendering practice (Costamagno, 2013). The site of Les Pradelles, some $100 \mathrm{~km}$ north of Roc de Marsal, is also attributed to the Quina Mousterian. As at Roc de Marsal, the very well preserved faunal material from the Quina layers at Les Pradelles is dominated by reindeer, 95\% of the remains are shaft fragments and evidence of fire use is scarce (Costamagno et al., 2006). At Les Pradelles, bone grease consumption has already been suggested (Costamagno, 2013). This hypothesis has also been proposed for the Saint-Marcel cave and the Baume des Peyrards cave (Daugeard, 2008) and for Layer 2 of the Roc de Marsal (Soulier, 2007).

Identifying bone grease rendering in the Middle Palaeolithic of Western Europe with certainty is hindered by the scarcity of fire-cracked rocks. But, as Speth (2015: 57) states, "one can easily and effectively boil in perishable containers made of bark, hide... or paunches placed directly on the fire and without using heated stones". This had been observed in ethnohistoric contexts but "we have no effective way, as yet at least, of "seeing" boiling in the 
archaeological record." As at Les Pradelles and Noisetier, fire-cracked stones were not recovered from any of the layers at Roc de Marsal. The ubiquitous plaquettes of limestone that are found in the deposits of all three sites have not been systematically studied for traces of bone crushing activities, but their fragility may prevent preservation of percussion traces (at least, for the relatively soft Turonian limestone found at Roc de Marsal). Yet, as discussed above, human behaviour seems to be the most logical explanation for the missing spongy and articular bone component. Study of fine screen refuse in comparison with thin section observations has been started (NISP $=19,631)$. It shows that the spongy bone is not particularly abundant among the small fragments (see Fig. 5). Following systematic crushing, very small fragments of spongy portions might have been entirely destroyed by boiling, consumption (and digestion) and/or post-depositional processes.

Considering the almost total destruction of articulations at Roc de Marsal, we propose that the processing of carcasses probably did not involve the initial disarticulation of individual bones prior to the breakage of long bone shafts for marrow extraction (cf. Castel 1999, 2010). More likely, the articulated joints were left intact during the process of marrow extraction. If bones were systematically sucked and chewed, it would have affected not only spongy parts of bones but also some compact ones. This would probably necessitate a systematic smashing of isolated articular regions before chewing. Bone consumption might have been an important component of foraging behaviour during the Middle Palaeolithic and might not be limited to fragile spongy bones. Thus, there could be significant differences between what is observed in ethnographical contexts and what we observe at Roc de Marsal. This difference could be related to differences in the craniofacial morphology of Neandertals compared to recent modern humans. Based on 3-dimensional analysis of facial morphology, the force of Neandertal jaws does not appear to have been significantly greater, but natural selection probably did favour slightly larger tooth size and better resistance to abrasion (O'Connor et al., 2005). Consequently, ethnographic data on bone consumption by modern humans (e.g., White, 1992; Boulestin, 1999) may not be of direct use in Neandertal zooarchaeological research. Bone consumption would potentially leave traces of digestion. However, in Layer 4 the bones from articular regions of limbs and axial skeleton is simply missing and there is little evidence that it was eaten. As mentioned above, $1.3 \%$ of the bones, including shafts, have identifiable gnaw or digestion marks. The hypothesis that gnawing or pounding of bones was a common practice among some Neandertal populations remains very tentative, but as 
Costamagno (2013) states, there currently seems to be no other logical explanations for some characteristics of the faunal assemblage.

\subsection{Site function}

For the Quina Mousterian occupations of Les Pradelles, Costamagno et al. (2006) and Rendu et al. (2012) argue that the nature of the faunal and lithic assemblages support the interpretation that Les Pradelles was used as a special-purpose site for short-term occupation, where portions of reindeer carcasses acquired during mass-kill events were transported from the kill site for further processing, rather than a base camp.

Based on the similarities in faunal assemblages (skeletal patterns, intensity of bone processing, potential catastrophic mortality profile, scarcity of carnivore damage and of burnt bones), the lack of living structures such as fireplaces and the high fauna- to-lithic ratio apparent in Layer 4 at Roc de Marsal (cf. Table 1), a similar argument could be made. However, important arguments put forward by Costamagno et al. (2006) and Rendu et al. (2012) for Les Pradelles involve evidence of short-term occupations from lithic analyses as well as a potential acquisition of reindeer carcasses through seasonal hunting events. Seasonal data acquired for the Roc de Marsal Layer 4 are few and do not seem to reflect seasonal masskill events. No information concerning the length of occupations is yet available and no direct comparison of lithic and faunal materials has been conducted for Roc de Marsal Layer 4. It is thus not yet possible to compare the two sites comprehensively.

Nonetheless, the detailed analyses of reindeer bones from Layer 4 would suggest that, except for an unknown proportion of crania and phalanges, the best interpretation is that most, if not all, the missing skeletal parts must have been destroyed in the cave. Thus, the carcasses were intensively and extensively butchered in the cave. Roc de Marsal Layer 4 could thus correspond either to a base camp or a second butchery site. This discussion is certainly not closed, and no doubt further excavations and analyses in these and other Middle Palaeolithic sites will allow further reflections and potentially new perceptions of Neanderthal adaptations in Western Europe.

\section{Conclusion}

The analysis of the Roc de Marsal fauna is particularly informative; zooarchaeological analysis has been performed on a large quantity of well-preserved skeletal material recovered 
during modern excavations with meticulous procedures that included the recovery of the very small fraction through wet-screening. This has allowed the potential identification of subsistence-related activities with a high degree of complexity. Detailed analyses have provided some insights into characteristics of Neandertal foraging behaviour during the Quina Mousterian.

During the Quina occupations at Roc de Marsal, Neandertals mostly based their subsistence on intensive reindeer hunting. It is still difficult to know if this pattern reflects prey availability or a deliberate selection. It is strongly suspected that a large part of the carcasses were disarticulated and fragmented after their introduction to the site. Butchering activities at the site were intensive and included systematic defleshing, marrow recovery and sinew removal. Some bone fragments were also used as retouchers. Bones in general have been intensively broken. Articular joints, left whole in a first step, might have been subsequently crushed in a second step. This pattern could correspond to an integrated process of removing the marrow and retaining the remaining consumable components of the limb joints. The results of taphonomic analysis associated to the lack of fire use at Roc de Marsal led us to suggest that the scarcity of spongy bones is best explained by grease extraction through crushing, as proposed for some other Middle Palaeolithic sites in southwestern France (Costamagno, 2013). There is no evidence that heat was used to facilitate the extraction of bone grease, as is typically the case among some recent prehistoric and extant hunter-gather societies. Bones may have been crushed simply to facilitate the consumption of their grease content through gnawing and sucking on the fragments.

The data from Roc de Marsal and from other recently excavated Middle Palaeolithic assemblages (e.g., Costamagno et al., 2006; Cochard et al., 2012; Mallye et al., 2012; Morin and Laroulandie 2012; Niven et al., 2012; Rendu et al., 2012; Costamagno, 2013; Niven, 2013; Romandini et al., 2014; Martisius et al., 2015) allow the suggestion of new ideas and points of view, and provide a deeper understanding of the potential diversity of Neandertal exploitation of animal by-products, for both alimentary and technical purposes.

\section{Acknowledgements}

The research at Roc de Marsal has the financial support of the US National Science Foundation (Grants \#09177739 and \#0551927), the Leakey Foundation, the University of Pennsylvania Research Foundation, the Service Régional de l'Archéologie d'Aquitaine and 
the Conseil Général de la Dordogne. The translation into English was done by Robert Winslow, John Hollier and the Roc de Marsal team. In the Natural History Museum from Geneva photographs were taken by Philippe Wagneur, drawings made by Florence Marteau and removal of concretion on bones by Jean-Marie Zumstein. Finally we would like to thank Sandrine Costamagno, especially for the bibliographic research on contemporary analogies she made to explain the characteristics of the faunal assemblage from the Noisetier cave, and Bruno Maureille. The first author would like to thank especially the team conducting the excavations for their promotion of these provocative opinions about the Roc de Marsal assemblages.

\section{References}

Abe, Y., 2005. Hunting and butchering patterns of the evenki in the Northern Transbaikalia Russia. Stony Brook University, Ph. D., New-York.

Aldeias, V., Goldberg, P., Sandgathe, D., Berna, F., Dibble, H.L., McPherron, S.P., Turq, A., Rezek Z. 2012. Evidence for Neandertal use of fire at Roc de Marsal (France). Journal of Archaeological Science 39, 2414-2423.

Antignac, G., 1998 - Etude du matériel lithique de la couche II du Roc de Marsal, Campagnedu-Bugue, Dordogne. DEA, Université de Bordeaux I.

Airvaux, J., 2004. Le site paléolithique de Chez-Pinaud à Jonzac, Charente-Maritime. Préhistoire du Sud-Ouest, supplément $n^{\circ} 8$.

Binford, L. R., 1978. Nunamiut Ethnoarchaeology. New York: Academic Press.

Binford, L. R., 1981. Bones: Ancient Men and Modern Myths. New York: Academic Press.

Binford, L. R., 1984. Faunal Remains from Klasies River Mouth. Academic Press, New York.

Binford, L. R., 1989. Isolating the transition to cultural adaptations: an organizational approach. In: Trinkaus, E. (Ed.), The Emergence of Modern Humans. Biocultural Adaptations in the Late Pleistocene. Cambridge University Press, Cambridge, pp. 18-41. 
Bordes, F. 1975. Le gisement du Pech de l'Azé IV: note préliminaire. Bulletin de la Société Préhistorique Française, t. 72, études et travaux, 1975, pp. 293-308.

Bordes, F. et Lafille, J., 1962. Découverte d'un squelette d'enfant moustérien dans le gisement du Roc de Marsal, commune de Campagne-du-Bugue (Dordogne). Compte-rendus de l'Académie des sciences 254, 714-715.

Bouchud, J., 1966. Essai sur le Renne et la climatologie du Paléolithique moyen et supérieur. Périgueux, Imprimerie Magne.

Boulestin, B., 1999. Approche taphonomique des restes humains. Le cas des Mésolithiques de la grotte des Perrats et le problème du cannibalisme en Préhistoire récente européenne. Oxford Archaeopress: BAR International Series 776.

Brink, J.W., 1997. Fat content in leg bones of Bison bison, and applications to archaeology. Journal of Archaeological Science 24, 259-274.

Bunn, H.T., Bartram, L.E., Kroll, E.M., 1988. Variability in bone assemblage formation from Hadza hunting, scavenging, and carcass processing. Journal of Anthropological Archaeology 7 (4), 412-457.

Castel, J.-C., 1999. Comportements de subsistance au Solutréen et au Badegoulien d'après les faunes de Combe Saunière (Dordogne) et du Cuzoul de Vers (Lot). Ph.D. thesis Université Bordeaux I.

Castel, J.-C., 2003. Économie de chasse et d'exploitation de l'animal au Cuzoul de Vers (Lot) au Solutréen et Badegoulien. Bulletin de la Société préhistorique Française 100 (1), 41-66.

Castel, J.-C., 2004. Analyse archéozoologique de la faune. In : Sangathe, D.,Turq, A., McPherron, S.J.P., Dibble, H.L. : Roc-de-Marsal (Campagne-du-Bugue, Dordogne), Rapport de d'opération 2004. Bordeaux, Service Régional de l'Archéologie d'Aquitaine. pp. 161-169.

Castel, J.-C., 2005. Economie préhistorique, boucherie et décompte des fragments osseux. Revue de Paléobiologie, Genève, vol. spéc. 10, Hommages à Louis Chaix. pp. 23-30. 
Castel, J.-C. 2010a. The faunal remains at Roc-de-Marsal (Campagne-du-Bugue, Dordogne, France) and game exploitation in the Quina mousterian. Poster presented for ICAZ, Paris, august 2010 .

Castel, J.-C., 2010b. Comportements de subsistance au Solutréen et au Badegoulien d'après les faunes de Combe Saunière (Dordogne) et du Cuzoul de Vers (Lot). Editions universitaires Européennes, Sarrebrück.

Castel J.-C., 2011. Archéozoologie de l'Aurignacien de l'Abri Castanet (Sergeac, Dordogne, France) : les fouilles 1994-1998. Revue de Paléobiologie, Genève 30 (2), 783-815.

Castel J.-C., 2012. Archéozoologie. In: Clottes, J., Giraud, J.-P., Chalard, P. (Dir.), Solutréen et Badegoulien au Cuzoul de Vers. Des chasseurs de rennes en Quercy. Liège, ERAUL 131, 209-268.

Castel J.-C., Boudadi-Maligne, M., Ducasse, S., Renard, C., Chauvière, F.-X., Kuntz, D., Mallye, J.-B., 2014. Animal exploitation strategies in Eastern Aquitaine (France) during the Last Glacial Maximum. In: Foulds, F.W.F., Drinkall, H.C., Perri, A.R., Clinnick, D.T.G., Walker, J.W.P. (Eds.), Wild Things: recent advances in Palaeolithic and Mesolithic research. Durham symposium 2012 march 24-25, Oxbow Books, pp. 160-174.

Castel, J.-C., Coumont, M.-P., Brugal, J.-P., Laroulandie, V., Camus, H., Chauvière, F.-X., Cochard, D., Guadelli, J.-L., Kuntz, D., Martin, H., Mourre, V., 2008. La fin du Paléolithique supérieur en Quercy: l'apport de l'Igue du Gral (Sauliac-sur-Célé, Lot). In: Jaubert, J., Ortega, I., Bordes, J.-G. (Eds.), Les sociétés du Paléolithique dans un Grand Sud-Ouest: nouveaux gisements, nouveaux résultats, nouvelles méthodes. Journées de la Société Préhistorique Française, Bordeaux, 24-25 novembre 2006. Société Préhistorique Française, Mémoire XLVII, pp. 335-353.

Castel J.-C., Soulier, M.-C., Hodgkins, J., 2007. Analyse archéozoologique de la faune. In: Sandgathe, D.M., Turq, A. Dibble, H.L., McPherron, S.P., Goldberg, P., Roc de Marsal (Campagne-du-Bugue, Dordogne): Rapport de fouille programmée triannuelle 2005-2007. Bordeaux, Service Régional de l'Archéologie d'Aquitaine, pp. 146-160. 
Chase, P., 1989. How different was Middle Paleolithic subsistence?: a zooarchaeological perspective on the Middle to the Upper Palaeolithic transition. In: Mellars, P., Stringer, C. (Eds.), The Human Revolution. Princeton University Press, Princeton, pp. 321-337.

Cochard, D., Brugal, J.-P., Morin, E., Meignen, L., 2012. Evidence of small fast game exploitation in the Middle Paleolithic of Les Canalettes, Aveyron, France. Quaternary International 264, 32-51.

Costamagno, S., 1999. Stratégies de chasse et fonction des sites au Magdalénien dans le Sud de la France. Ph.D. thesis Université Bordeaux I.

Costamagno, S., 2012. Des stries de boucherie aux sous-systèmes techniques de transformation et de consommation des ressources animales: apports de l'approche expérimentale. Thèse d'HDR de l’Université de Bordeaux.

Costamagno, S., 2013. Bone Grease Rendering in Mousterian Contexts: The Case of Noisetier Cave (Fréchet-Aure, Hautes-Pyrénées, France), In: Clark J.L., Speth J.D. (Eds.), Zooarchaeology and Modern Human Origins, Amsterdam, Springer, pp. 209-225.

Costamagno, S., David, F., 2009. Comparaison des pratiques bouchères et culinaires de différents groupes sibériens vivant de la renniculture. Archaeofauna 19, 9-25.

Costamagno, S., Rigaud, J.-P., 2014. L'exploitation de la graisse au Paléolithique. L'exploitation de la graisse au Paléolithique. In: Costamagno S. (dir.), Histoire de l'alimentation humaine: entre choix et contraintes. 138ème Congrès du CTHS, Rennes, 22-27 avril 2013, Paris, CTHS, pp. 134-152.

Costamagno, S. Meignen, L., Beauval, C., Vandermeersch, B., Maureille, B., 2006. Les Pradelles (Marillac-le-Franc, France): A mousterian reindeer hunting camp ? Journal of Anthropological Archaeology 25 (4), 466-484.

Costamagno S., Théry-Parisot I., Castel, J.-C. Brugal J.-Ph., 2009. Combustible ou non ? Analyse multifactorielle et modèles explicatifs sur des ossements brûlés paléolithiques. In: Théry-Parisot, I., Costamagno, S., Henry, A. (Eds.), Fuel and Management during the 
Palaeolithic and Mesolithic periods: new tools, new interpretations. BAR Int. Series 1914 : 65-84. Actes du colloque international de l'IUSPP, Lisbonne 2006. pp. 65-84.

Daujeard, C., 2008. Exploitation du milieu animal par les Néandertaliens dans le Sud-Est de la France Oxford: BAR International Series 1867.

Delpech, F., 1996. L'environnement animal des Moustériens Quina du Périgord. Paleo 8, 3146.

Delpech, F., Villa, P., 1993. Activités de chasse et de boucherie dans la Grotte des Eglises. In Desse, J., Audoin-Rouzeau, F. (Dir.): Exploitation des animaux sauvages à travers le temps. XIIIe rencontres internationales d'Archéologie et d'Histoire d'Antibes. Actes des rencontres, 15-16-17 octobre 1992. Juan-les-Pins, APDCA, pp. 79-102.

Denys, N., 1672. Histoire naturelle des peuples, des animaux, des arbres et plantes de l'Amérique septentrionale et de ses divers climats (Vol. 2). Paris: Claude Barrin.

Dibble, H.L., Holdaway, S. J., Lenoir, M., McPherron, S.P., Roth, B., Sanders-Gray, H., 1995. Techniques of Excavation and Analysis. Chapter 3 in The Middle Paleolithic Site of CombeCapelle Bas (France). Dibble, H., and M. Lenoir (Eds.), Philadelphia: University Museum Press.

Dibble H.L., McPherron, S.P., 2006. The missing Mousterian. Current Anthropology 47, 777803.

Discamps, E., 2011. Hommes et hyènes face aux recompositions des communautés d'Ongulés (MIS 5-3). Ph.D. thesis Université Bordeaux I.

Discamps, E., 2014. Ungulate Biomass Fluctuations Endured by Middle and Early Upper Paleolithic Societies (SW France, MIS 5-3): The Contributions of Modern Analogs and Cave Hyena Paleodemography. Quaternary International 337, 64-79.

Discamps, E., Costamagno, S., 2015. Improving mortality profile analysis in zooarchaeology: a revised zoning for ternary diagrams. Journal of Archaeological Science 58, 62-76. 
Discamps, E., Jaubert, J., Bachellerie, F., 2011. Human choices and environmental constraints: deciphering the variability of large game procurement from Mousterian to Aurignacian times (MIS 5-3) in southwestern France. Quaternary Science reviews 30 (19-20), $2755-2775$.

Discamps, E., Royer, A., this issue. A cross-scale approach to the palaeoenvironmental conditions of Mousterian hunters in southwestern France (MIS 5-3): combining data from large and small mammal communities. Quaternary International, submitted.

Fletcher, W.J., Sánchez Goñi, M.F., Allen, J.R.M., Cheddadi, R., Combourieu-Nebout, N., Huntley, B., Lawson, I., Londeix, L., Magri, D., Margari, V., Müller, U.C., Naughton, F., Novenko, E., Roucoux, K., Tzedakis, P.C., 2010. Millennial-scale variability during the last glacial in vegetation records from Europe. Quaternary Science Reviews 29, 2839-2864.

Gaudzinski, S. 1995. Wallertheim revisited: a re-analysis of the fauna from the Middle Palaeolithic site of Wallertheim (Rheinhessen/Germany). Journal of Archaeological Science $22,51-66$.

Gaudzinski, S., Roebroeks, W., 2000. Adults only, reindeer hunting at the Middle Paleolithic site Salzgitter Lebenstedt, Northern Germany. Journal of Human Evolution 38, 497-521.

Gifford-Gonzalez, D., 1989. Modern analogues: Developing an interpretative framework. In: Bonnichsen, R. Sorg, M. (Eds.), Bone modification. Orono, Maine: Center for the Study of First Americans, pp. 43-52.

Goldberg, P., Aldeias, V., Dibble, H.L., McPherron S.J.P., Sandgathe D.M., Turq, A., 2013. Testing the Roc de Marsal Neandertal "Burial" with Geoarchaology. Archaeological and Anthropological Science, special issue: Geoarchaeology of Ritual Behavior and Sacred Places, 1-11.

Goldberg, P., Dibble, H.L., Berna, F., McPherron, S.J.P., Sandgathe, D., Turq, A., 2012. New evidence on Neandertal use of fire: Examples from Roc de Marsal and Pech de l'Azé IV. Quaternary International 247, 325-340. 
Gronnow, B., Meldgaard, M., \& Berglund Nielsen, J., 1983. Aasivissuit - The great summer camp. Archaeological, ethnographical and zoo-archaeological studies of a caribou-hunting site of the West Greenland (Vol. 5). Meddelelser om Gronland: Man and Society.

Guadelli, J.-L., 1987. Contribution à l'étude des zoocénoses préhistoriques en Aquitaine (Würm ancien et interstade Würmien). Ph.D. thesis Université Bordeaux I.

Guérin, G., Discamps, E., Lahaye, C., Mercier, N., Guibert, P., Turq, A., Dibble, H.L., McPherron, S.P., Sandgathe, D., Goldberg, P., Jain, M., Thomsen K., Patou-Mathis, M., Castel, J.-C., Soulier, M.-C., 2012. Multi-method (TL and OSL), multi-material (quartz and flint) dating of the Mousterian site of Roc de Marsal (Dordogne, France): correlating Neanderthal occupations with the climatic variability of MIS 5-3. Journal of Archaeological Science 39 (10), 3071-3084.

Guérin, G., Frouin, M., Tuquoi, J., Thomsen, K.J., Goldberg, P., Aldeias, V., Lahaye, C., Mercier, N., Guibert, P., Jain, M., Sandgathe, D., McPherron, S.P., Turq, A., Dibble, H.L., this issue.The complementarity of luminescence dating methods illustrated on the Mousterian sequence of the Roc de Marsal: A series of reindeer-dominated, Quina Mousterian layers dated to MIS 3. Quaternary International, submitted.

Hodgkins, J.M., 2012 Tracking Climate-Driven changes in Neandertal Subsistence Behaviors and Prey Mobility Patterns. PhD, Arizona State University.

Janzen, A., Reid, R.E.B., Vasquez, A., Gifford-Gonzalez, D., 2014. Smaller fragment size facilitates energy-efficient bone grease production. Journal of Archaeological Science 49: $518-523$.

Jaubert, J., Lorblanchet, M., Laville, H., Slott-Moller, R., Turq, A., Brugal, J.-P., 1990. Les Chasseurs d'Aurochs de la Borde: Un Site du Paléolithique Moyen (Livernon, Lot). DAF 27, Maison des Sciences de 1'Homme, Paris.

Karr, L.P., Short A.E.G., Hannus, LA., Outram, A.K., 2015. A bone grease processing station at the Mitchell Prehistoric Indian Village: Archaeological evidence for the exploitation of 
bone fats. Environmental Archaeology 20 (1), 1-12.

Kent, S., 1993. Variability in faunal assemblages: the influence of hunting skill, sharing, dogs, and mode of cooking on faunal remains at sedentary Kalahari community. Journal of Anthropological Archaeology 10, 1-26.

Lafille, J., 1961. Gisement dit «Roc de Marsal», commune de Campagne-du-Bugue (Dordogne). Bulletin de la Société Préhistorique Française 58 (11-12), 712-713.

Lam, Y.M., Chen, X., Pearson, O.M., 1999. Intertaxonomic variability in patterns of bone density and the differential representation of Bovid, Cervid, and Equid elements in the archaeological record. American Antiquity 64, 343-362.

Laquay, G., 1981 Recherches sur les faunes du Würm I en Périgord. Thèse de Doctorat de Géologie du Quaternaire et Préhistoire, Université Bordeaux I.

Leechman, D., 1951. Bone grease. American Antiquity 16, 355-356.

Manne, T.H., Stiner, M.C., Bicho, N.F., 2006. Evidence for Bone Grease Rendering During the Upper Paleolithic at Vale Boi (Algarve, Portugal). L'Anthropologie 114 (1), 48-67.

Mallye, J.-B.,Thiébaut, C., Mourre, V., Costamagno,S., Claud, E., Weisbeckerg, P., 2012. The Mousterian bone retouchers of Noisetier Cave: experimentation and identification of marks. Journal of Archaeological Science 39 (4), 1131-1142.

Marean, C.W., Frey, C.J., 1997. Animal bones from caves to cities: reverse utility curves as methodological artifacts. American Antiquity 62 (4), 698-711.

Martisius, N.L., Dogandzic, T., Lenoir, M., McPherron, S.P., Steele, T.E., 2015. Neandertal Subsistence at the Mousterian Site of Abri Peyrony, France. Poster presented for the Society for American Archaeology 80 ${ }^{\text {th }}$ Annual Meeting, San Francisco, California, April 15-19,2015.

Monahan, C.M., 1998. The Hadza carcass transport debate revisited and its archaeological implications. Journal of Archaeological Science 25 (5), 405-424. 
Morin, E., 2004. Late Pleistocene population interaction in Western Europe and modern human origins: New insights based on the faunal remains from Saint-Césaire, southwestern France. Thèse de doctorat, University of Michigan, Ann Arbor.

Morin, E., 2007. Fat composition and Nunamiut decision-making: a new look at the marrow and bone grease indices. Journal of Archaeological Science 34 (1), 69-82.

Morin, E., Laroulandie, V., 2012. Presumed Symbolic Use of Diurnal Raptors by Neanderthals. Plos One 7 (3), 1-5.

Morin, E., Delagnes, A., Armand, D., Castel, J.-C., Hodgkins, J., 2014. Millennial-scale change in archaeofaunas and their implications for Mousterian lithic variability in southwest France. Journal of Anthropological Archaeology 36: 158-180.

Morrison, D., 1998. Caribou hunters in the Western Arctic. Washington: University of Washington Press.

Murray, N.A., 1993. The behavioural ecology of reindeer (Rangifer tarandus) during the last glaciation in Britain and its implications for human settelment, subsistence and mobility, $\mathrm{Ph}$. D. thesis, University of Edinburgh, Scotland.

Niven, L., 2013. A diachronic evaluation of Neanderthal cervid exploitation and site use at Pech de l'Azé IV, France. 2012. In: Clark, J.L., Speth, J.D. (Eds.) Zooarchaeology and Modern Human Origins, Human Hunting Behavior during the Later Pleistocene, pp. 151-161.

Niven, L., Steele, T.E., Rendu, W., Mallye, J.-B., McPherron, S.P., Jaubert, J., Hublin, J.-J., 2012. Neandertal mobility and large-game hunting: The exploitation of reindeer during the Quina Mousterian at Chez-Pinaud Jonzac (Charente-Maritime, France). Journal of Human Evolution 63 (4), 624-635.

O’Connell, J.F., Hawkes, K., Blurton-Jones, N., 1988. Hadza hunting, butchering, and bone transport and their archaeological implications. Journal of Anthropological Research 44 (2), $113-161$. 
O’Connell, J.F., Marshall, B., 1989. Analysis of kangaroo body part transport among the Alyawara of Central Australia. Journal of Archaeological Science 16, 393-405.

O’Connor, C.F., Franciscus, R.G., Holton, N.E., 2005. Bite Force Production Capability and Efficiency in Neandertals and Modern Humans. American Journal of Physical Anthropology $127,129-151$.

Outram, A.K., 1999. A comparison of Paleo-Eskimo and medieval norse bone fat exploitation in Western Greenland. Arctic Anthropology 36 (1/2), 103-117.

Outram, A.K., 2001. A new approach to identifying bone marrow and grease exploitation: why the "indeterminate" fragments should not be ignored. Journal of Archaeological Science $28,401-410$.

Outram, A.K., 2003. Comparing Levels of Subsistence Stress amongst Norse Settlers in Iceland and Greenland using Levels of Bone Fat Exploitation as an Indicator. Environmental Archaeology 8 (2), 119-128.

Potapov, L.P., Levin, M.G., 1964. The Peoples of Siberia. University of Chicago Press,

Rendu, W., Costamagno, S., Meignen L., Soulier, M.-C., 2012. Monospecific faunal spectra in Mousterian contexts: implications for social behaviour. Quaternary International 247, 50-58.

Richter, D., Dibble, H., Goldberg, P., McPherron, S.P., Niven, L., Sandgathe, D., Talamo, S., Turq, A., 2013. The late Middle Palaeolithic in Southwest France: New TL dates for the sequence of Pech de l'Azé IV. Quaternary International 294, 160-167.

Romandini, M., Nannini, N., Tagliacozzo, A., Peresani, M., 2014. The ungulate assemblage from layer A9 at Grotta di Fumane, Italy: A zooarchaeological contribution to the reconstruction of Neanderthal ecology. Quaternary International 337, 11-27.

Saint-Germain, C., 2005. Animal fat in the cultural world of the Native Peoples of Northeastern America. In: Mulville, J., Outram, A. K. (Eds.), The zooarchaeology of fats, oils, 
milk and dairying. Durham symposium 2002 august. Oxford: Oxbow Books, pp. 107-113.

Sanchez Goñi, M.F., Landais, A., Fletcher, W.J., Naughton, F., Desprat, S., Duprat, J., 2008. Contrasting impacts of Dansgaard-Oeschger events over a western European latitudinal transect modulated by orbital parameters. Quaternary Science Reviews 27 (11-12), 11361151.

Sandgathe, D.M., Dibble, H.L., Goldberg, P., McPherron, S.P., 2011. The Roc de Marsal Neandertal child: A reassessment of its status as a deliberate burial. Journal of Human Evolution 61 (3), 243-253.

Sandgathe, D.M., Dibble, H.L., Goldberg, P., McPherron, S.P., Turq, A., Niven, L., Hodgkins, J., 2011 - On the Role of Fire in Neandertal Adaptations in Western Europe: Evidence from Pech de 1'Azé IV and Roc de Marsal, France. PaleoAnthropology 2011, 216-242.

Sandgathe, D.M., Dibble, H.L., Goldberg, P., McPherron, S.P., Turq, A. Schwortz, S., 2008. Roc de Marsal (Campagne-du-Bugue, Dordogne): Rapport d'opération pour l'année 2008. Bordeaux, Service Régional de l'Archéologie d'Aquitaine.

Schaefer, O., Steckle, J., 1980. Dietary habits and nutritional base of native populations of the Northwest Territories. Yellowknife, N.W.T: Dept. of Information, Government of the Northwest Territories.

Soulier, M.-C., 2007. Etude archéozoologique du carré M16 de la couche II du gisement moustérien du roc de Marsal (Dordogne). Université Toulouse 2 - Le Mirail, Mémoire de Master.

Speth, J.D., 2015. When Did Humans Learn to Boil? PaleoAnthropology, 2015, 54-67.

Speth, J.D., Tchernov, E., 2001. Neandertal hunting and meat-processing in the Near-East. Evidence from Kebara Cave (Israel). In: Stanford, C.B., Bunn, H.T. (Eds.), Meat-Eating and Human Evolution. Oxford University Press, Oxford, pp. 52-72.

Spiess, A., 1979. Reindeer and Caribou hunters: An Archaeological Study. New York, 
Academic Press.

Steele, T.E., Weaver, T.D., 2002. The Modified Triangular Graph: A Refined Method for Comparing Mortality Profiles in Archaeological Samples. Journal of Archaeological Science, 29 (3), 317-322.

Stiner, M.C., 1991. Food Procurement and transport by Human and Non-Human Predators. Journal of Archaeological Science 18, 455-482.

Stiner, M.C., 1994. Honor among Thieves: A Zooarchaeological Study of Neanderthal Ecology. Princeton University Press, Princeton.

Stiner, M.C., 2003. Zooarchaeological evidence for resource intensification in Algarve, Southern Portugal. Promontoria 1, 27-61.

Théry-Parisot, I., Costamagno, S., Brugal, J.-Ph., Castel, J.-C., Gerbe, M., Bouby, L., Guilbert, R., 2009. La question des os brûlés dans les sites du Paléolithique. Un programme d'archéologie expérimentale en taphonomie. Les nouvelles de l'archéologie 118, 31-36.

Thiébaut, C., 2003. L'industrie lithique de la couche III du Roc de Marsal (Dordogne): le problème de l'attribution d'une série lithique au Moustérien à denticulés. Paléo 15, 141-168.

Thiébaut, C., Claud, E., Costamagno, S., Coudenneau, A., Deschamps, M., Gerbe, M., Mourre, V., Val, A., Brenet, M., Chacón, M.-G., Chong, S., Coumont, M.-P., Colonge, D., Mallye, J.-B., Mussini, C., Provenzano, N. and Soulier, M.-C., 2011. Des Traces et des Hommes : Projet de recherche interdisciplinaire sur l'identification des modalités d'acquisition et de traitement des matières végétales et animales au Paléolithique moyen en Europe occidentale, rapport annuel du PCR, Service Régional de l'Archéologie de Midi-Pyrénées.

Turq, A., 1979. L'évolution du Moustérien de type Quina au Roc-de-Marsal et en Périgord: modification de l'équilibre technique et typologique. Toulouse, Ecole des Hautes Etudes en Sciences Sociales.

Turq, A., 1980. Le Roc-de-Marsal: Campagne-du-Bugue. In: Rigaud, J.-Ph. (Dir.), 
informations archéologique circonscription d'Aquitaine. Gallia-Préhistoire 23 (2), 402-403.

Turq, A., 1985. Le Moustérien de type Quina du Roc-de-Marsal (Dordogne). Bulletin de la Société Préhistorique Française 82 (2), 46-51.

Turq, A., 1988. Le Moustérien de type Quina du Roc-de-Marsal à Campagne (Dordogne): contexte stratigraphique, analyse lithologique et technologique. Documents d'Archéologie Périgourdine 3.

Turq, A., 1989. Le squelette de l'enfant du Roc-de-Marsal. Les données de la fouille. Paléo 1, $47-54$.

Turq, A., 1992. Le Paléolithique inférieur et moyen entre les vallées de la Dordogne et du Lot, Ph.D. thesis Université Bordeaux I.

Turq, A., Dibble, H.L., Faivre, J.-P., Goldberg, P., McPherron, S.J.P., Sandgathe, D., 2008. Le Moustérien Récent Du Périgord Noir : Quoi De Neuf? In : Jaubert, J., Bordes, J.-G., Ortega, I. (Eds.), Les Sociétés du Paléolithique dans un Grand Sud-ouest de la France: nouveaux gisements, nouveaux résultats, nouvelles méthodes. Mémoire de la Société Préhistorique Française 48, pp. 83-94.

Vehik, S.C., 1977. Bone fragments and bone grease manufacture: A review of their archaeological use and potential. Plains Anthropologist 22, 169-182.

Villa, P., Bon, F., Castel, J.-C., 2002. Fuel, fire and fireplaces in the Palaeolithic of Western Europe. Review of Archaeology 23 (1), 33-42.

Villa, P. Mahieu, E., 1991. Breakage Patterns of Human long Bones. Journal of Human Evolution 21, 27-48.

Weaver, T. D. Boyko, R.H., Steele, T.E., 2011. Cross-platform program for likelihood-based statistical comparisons of mortality profiles on a triangular graph. Journal of Archaeological Science 38 (9), 2420-2423. 
White, T.D., 1992. Préhistoric Cannibalism at Mancos 5MTUMR-2346. Princetown University Press.

Yellen, J.E., 1991. Small mammals: Kung San utilization and the production of faunal assemblages. Journal of Anthropological Archaeology 10, 1-6. 


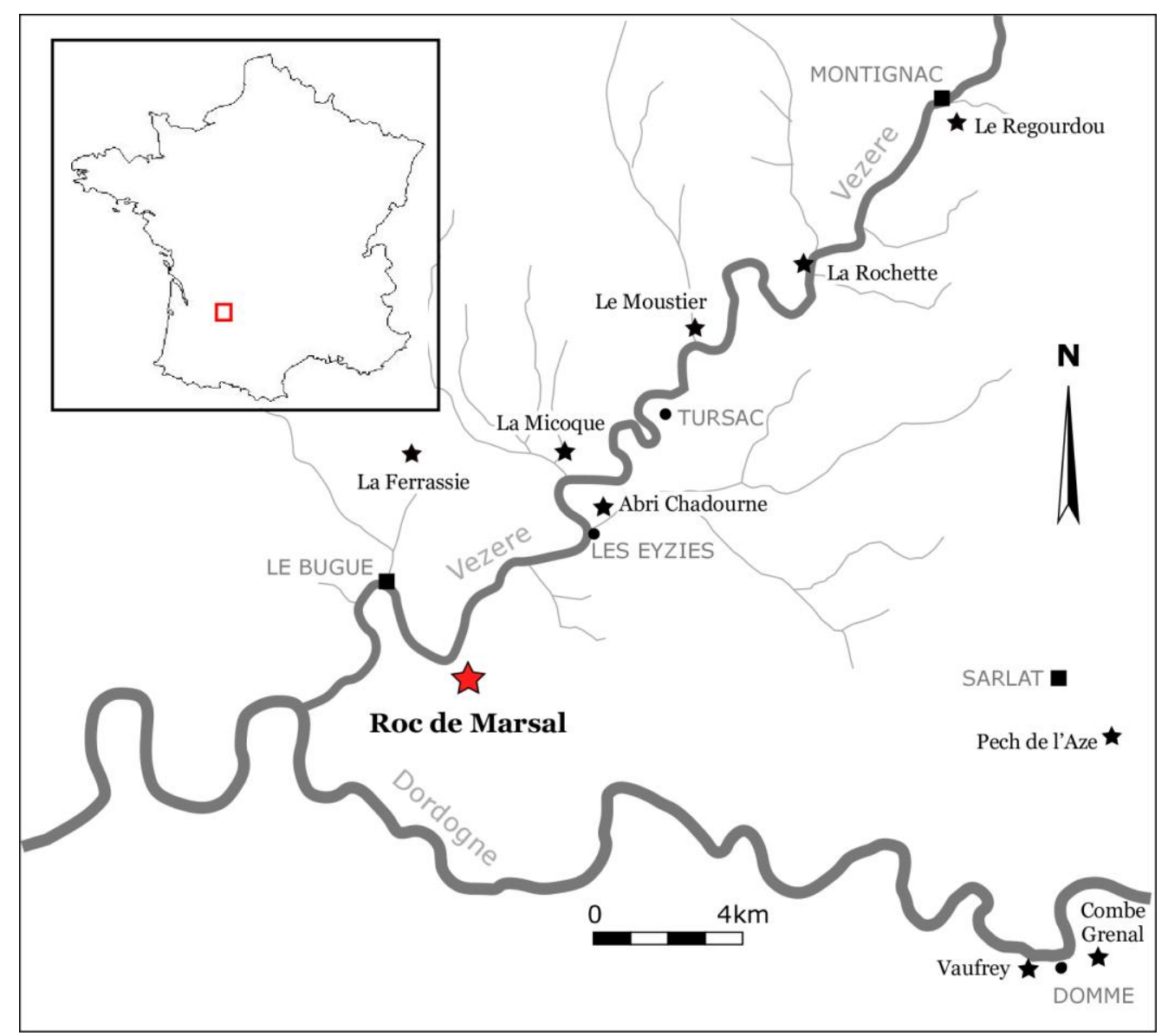




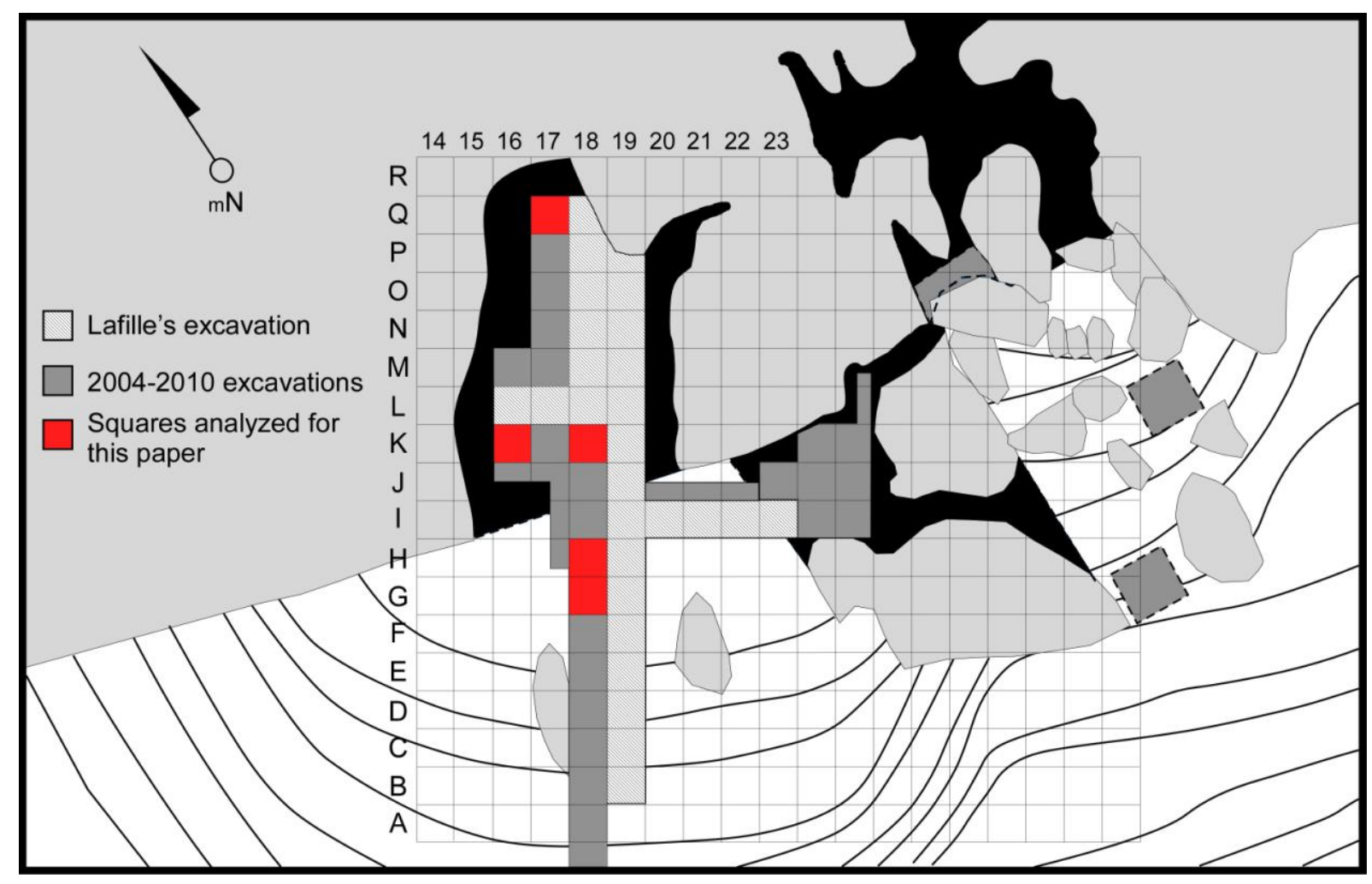



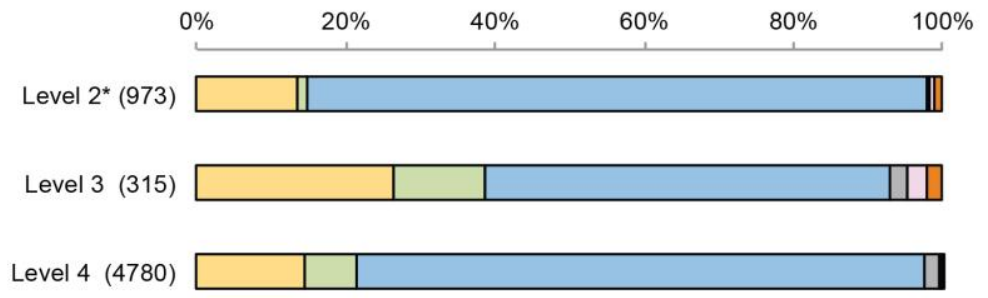

- Large mammals

$\square$ Bison to reindeer size mammals

口Reindeer size mammals

口Reindeer to chamois size mammals

Level 5 (634)

口Chamois size mammals

Level 7 (718)

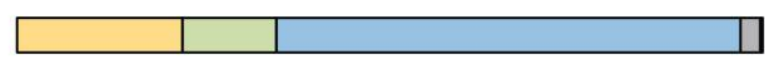

口Fox size vertebrates

a) Level $8+9(237)$

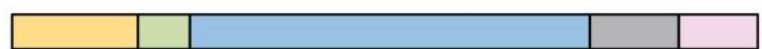

\begin{tabular}{llllll}
$0 \%$ & $20 \%$ & $40 \%$ & $60 \%$ & $80 \%$ & $100 \%$ \\
\hline
\end{tabular}

Level 2* (620)

$\square$

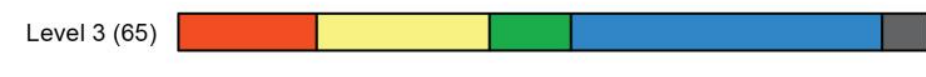

Level 4 (1312)

II

aBovines

口Horse

口Red deer

Level 5 (140)

\begin{tabular}{|l|l||}
\hline & \\
\hline
\end{tabular}

口Reindeer

口Ibex

ㅁRoe deer

Level 7 (108)

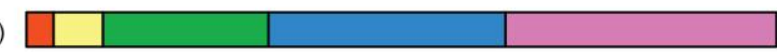

b) Level 8+9 (43) $\square \square \square$ 


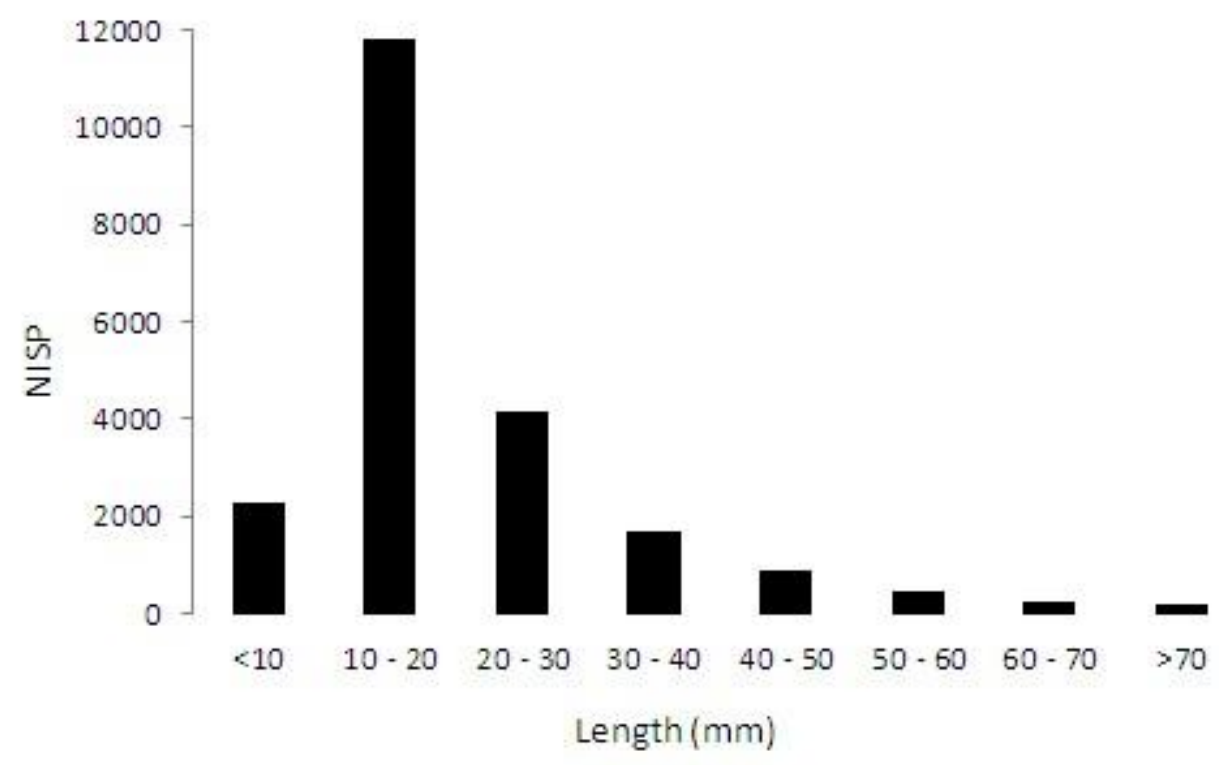




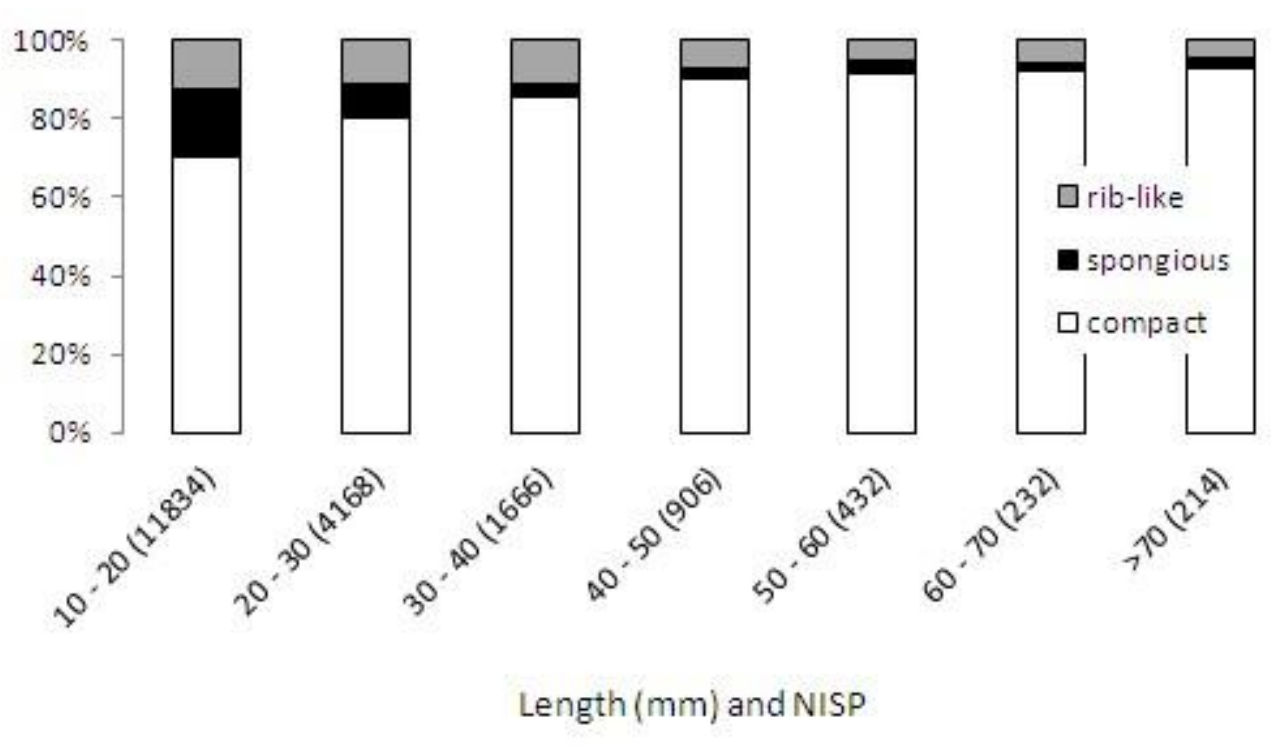




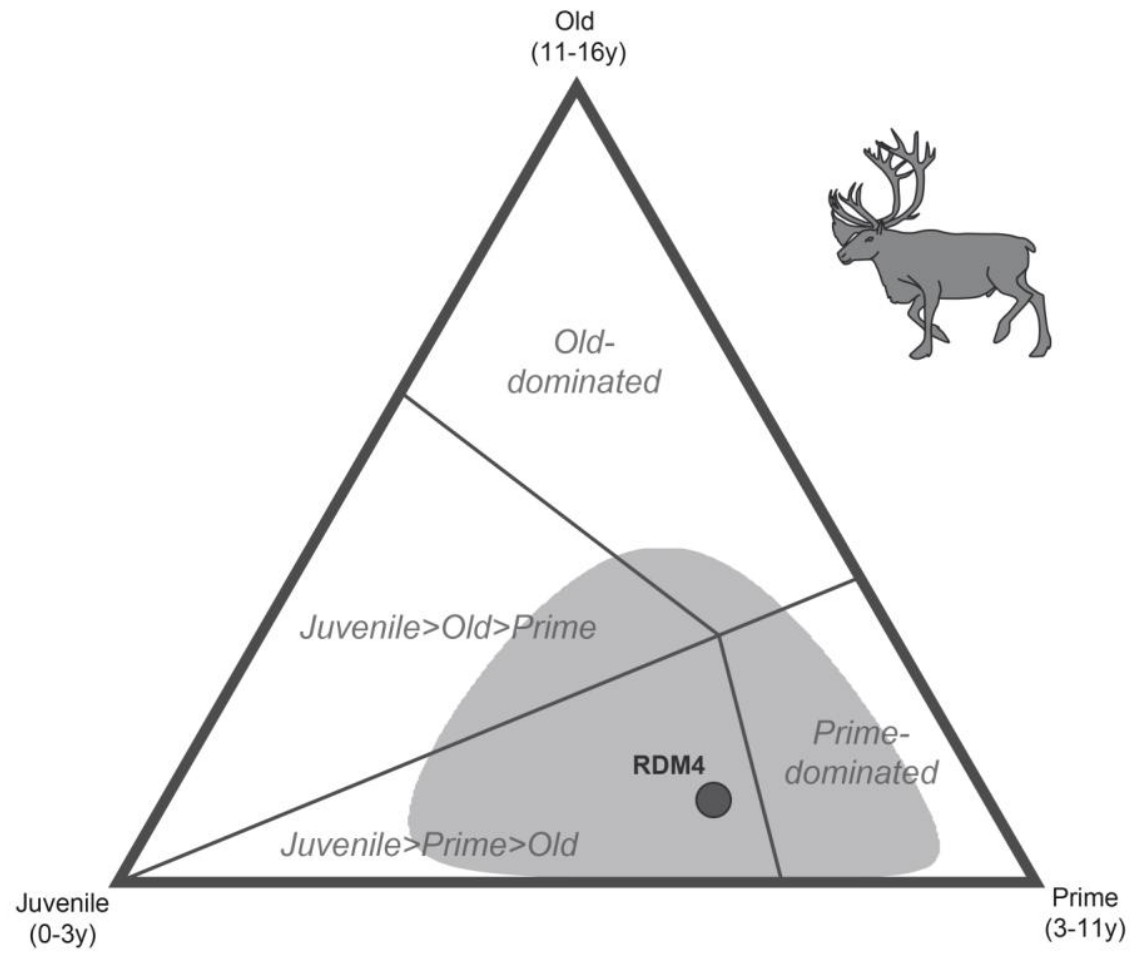




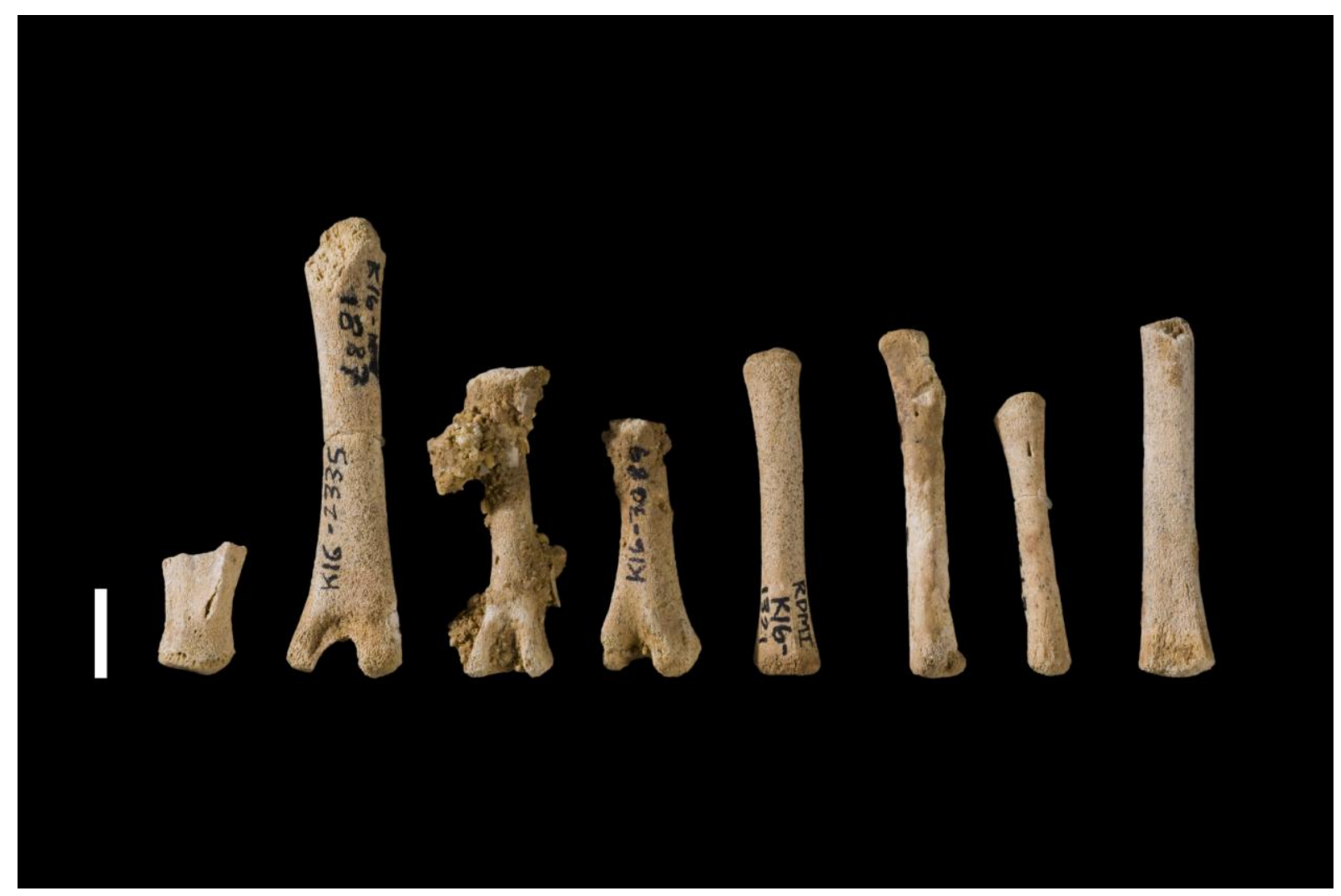




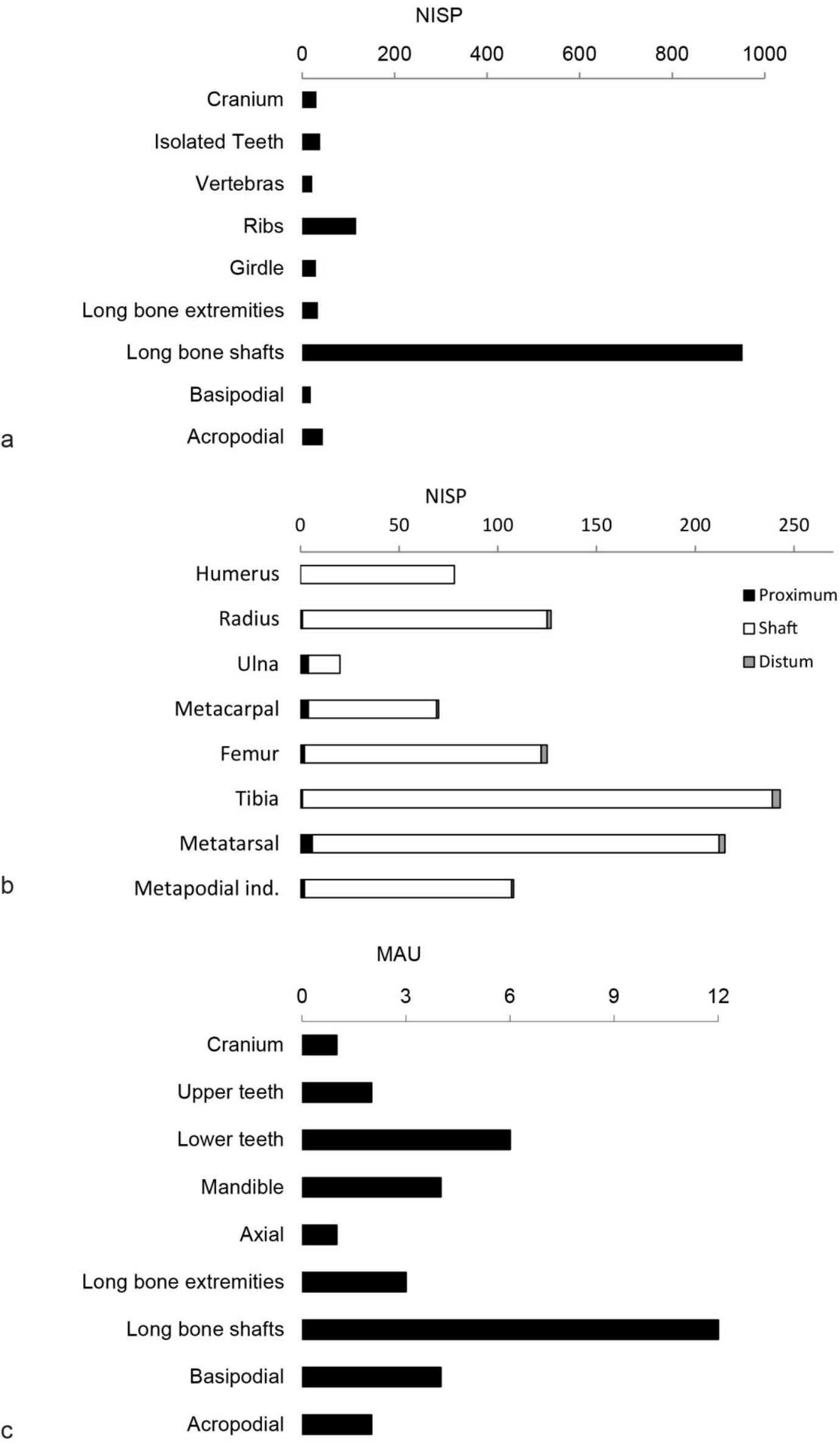




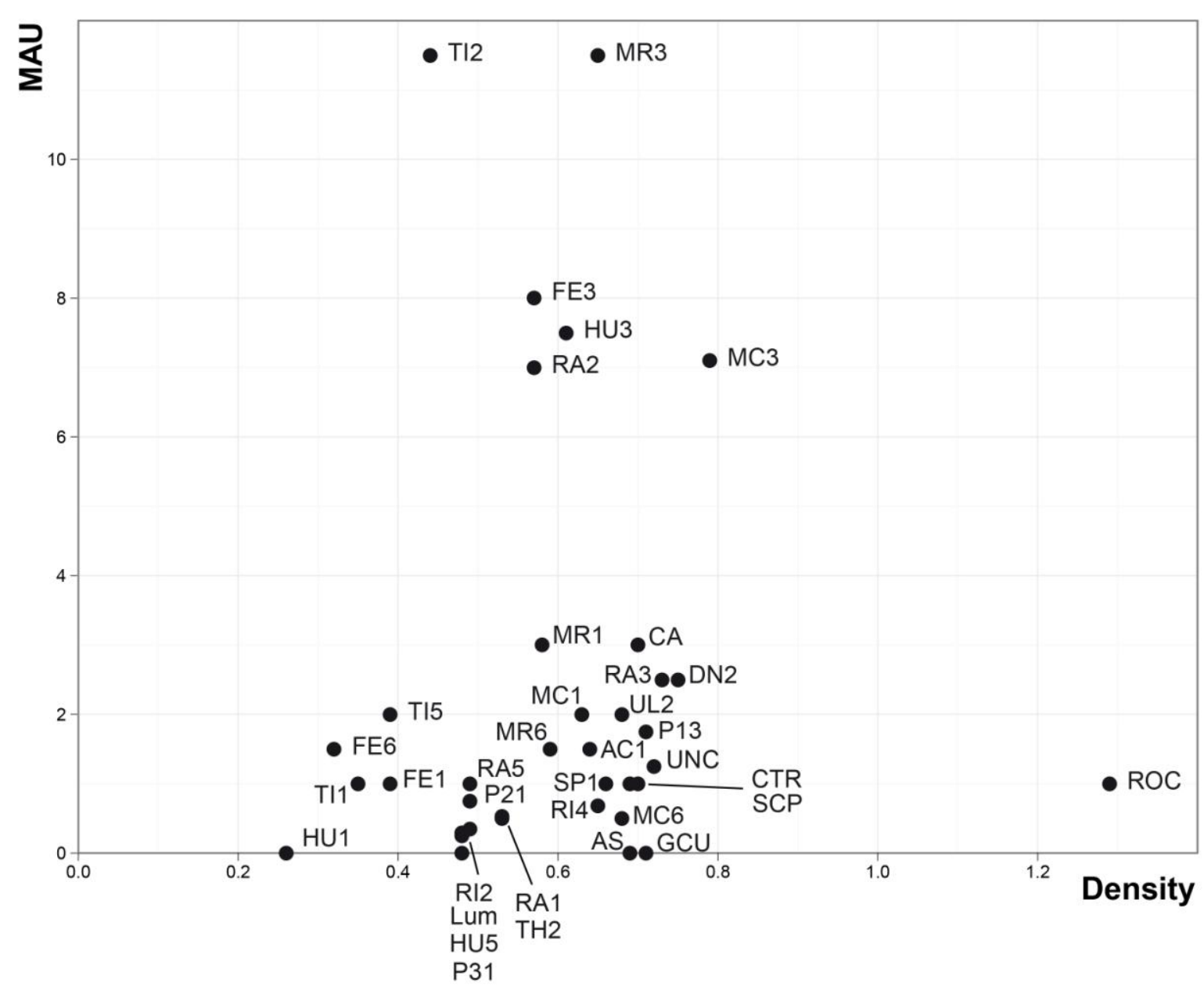




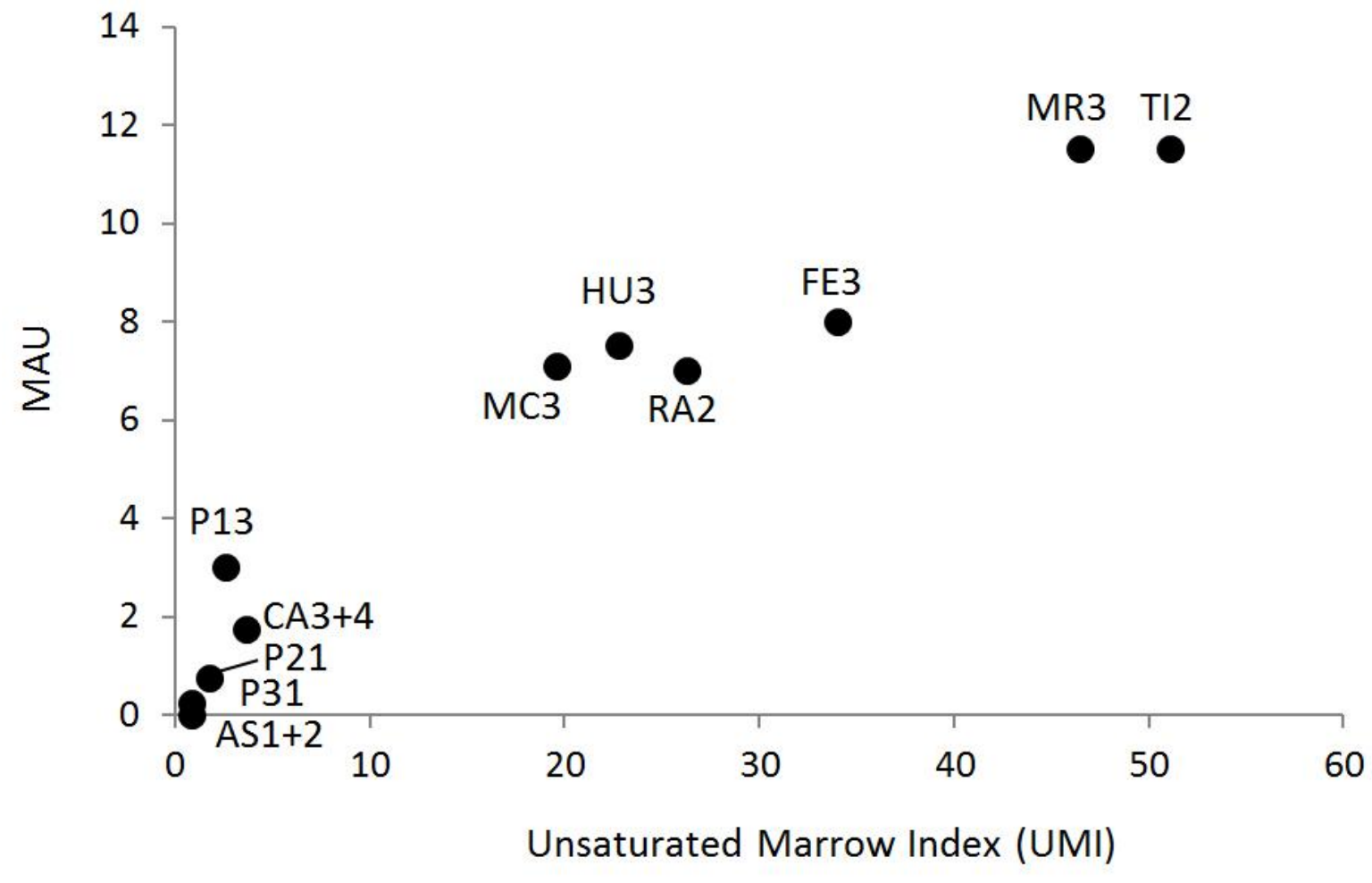




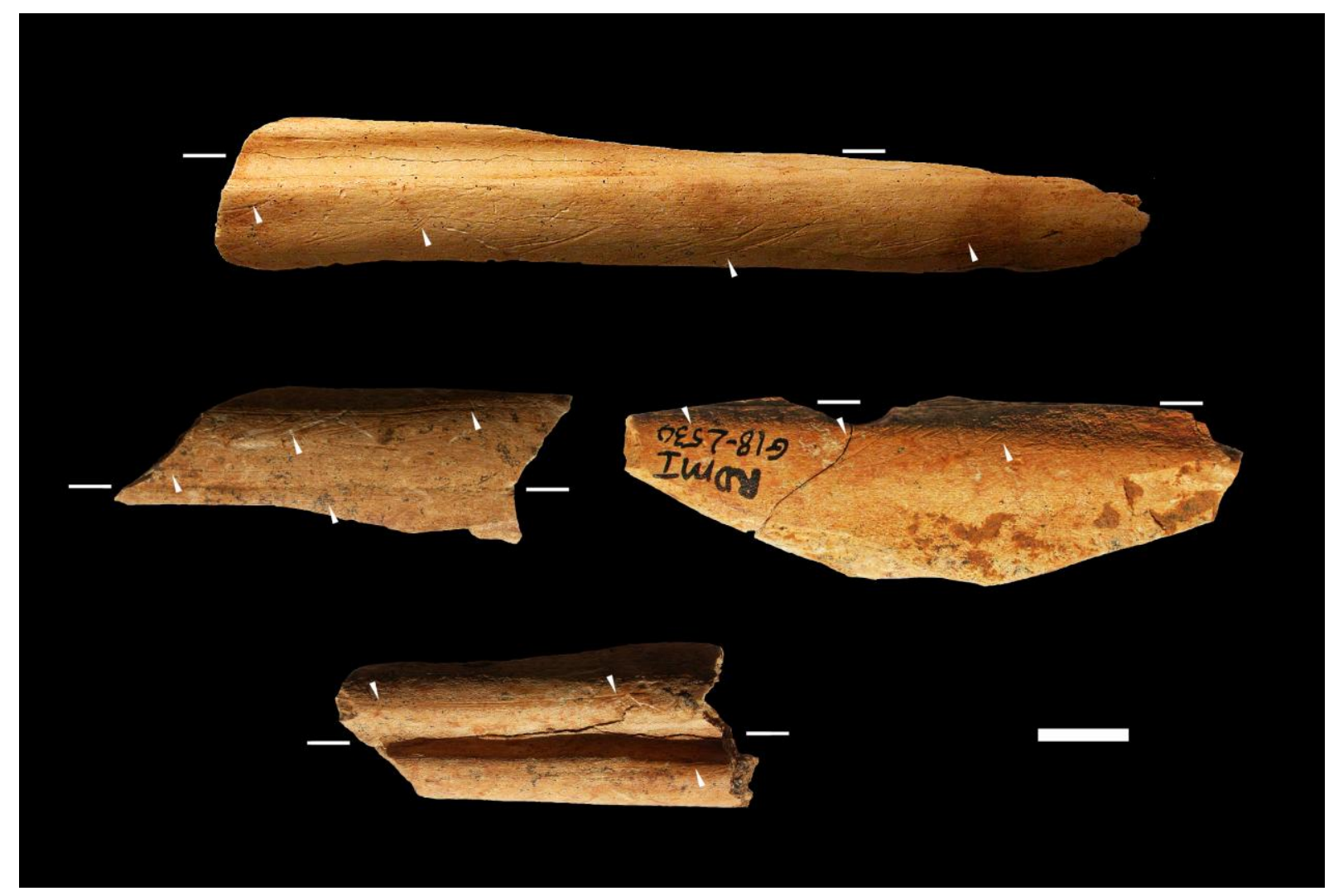




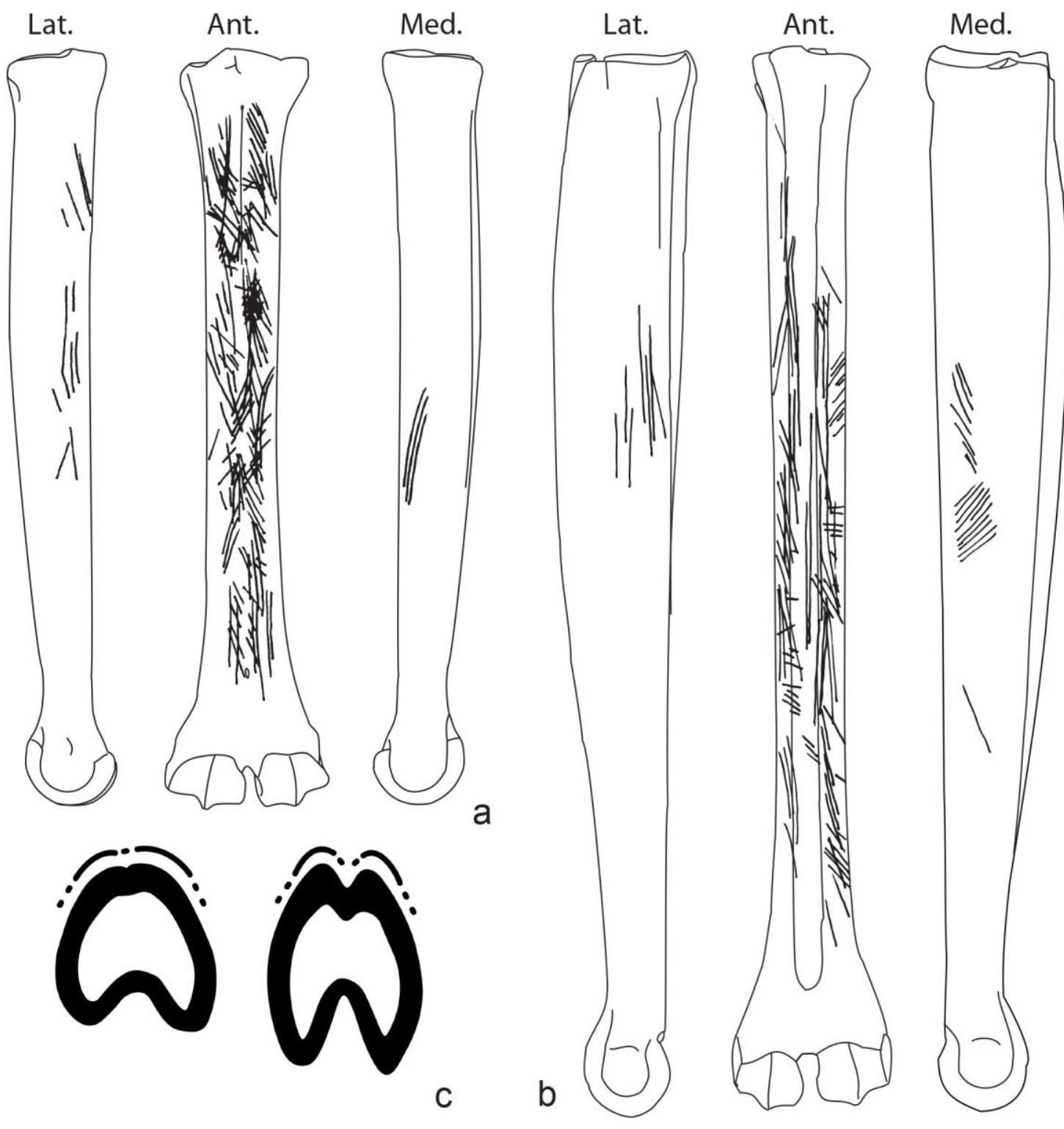




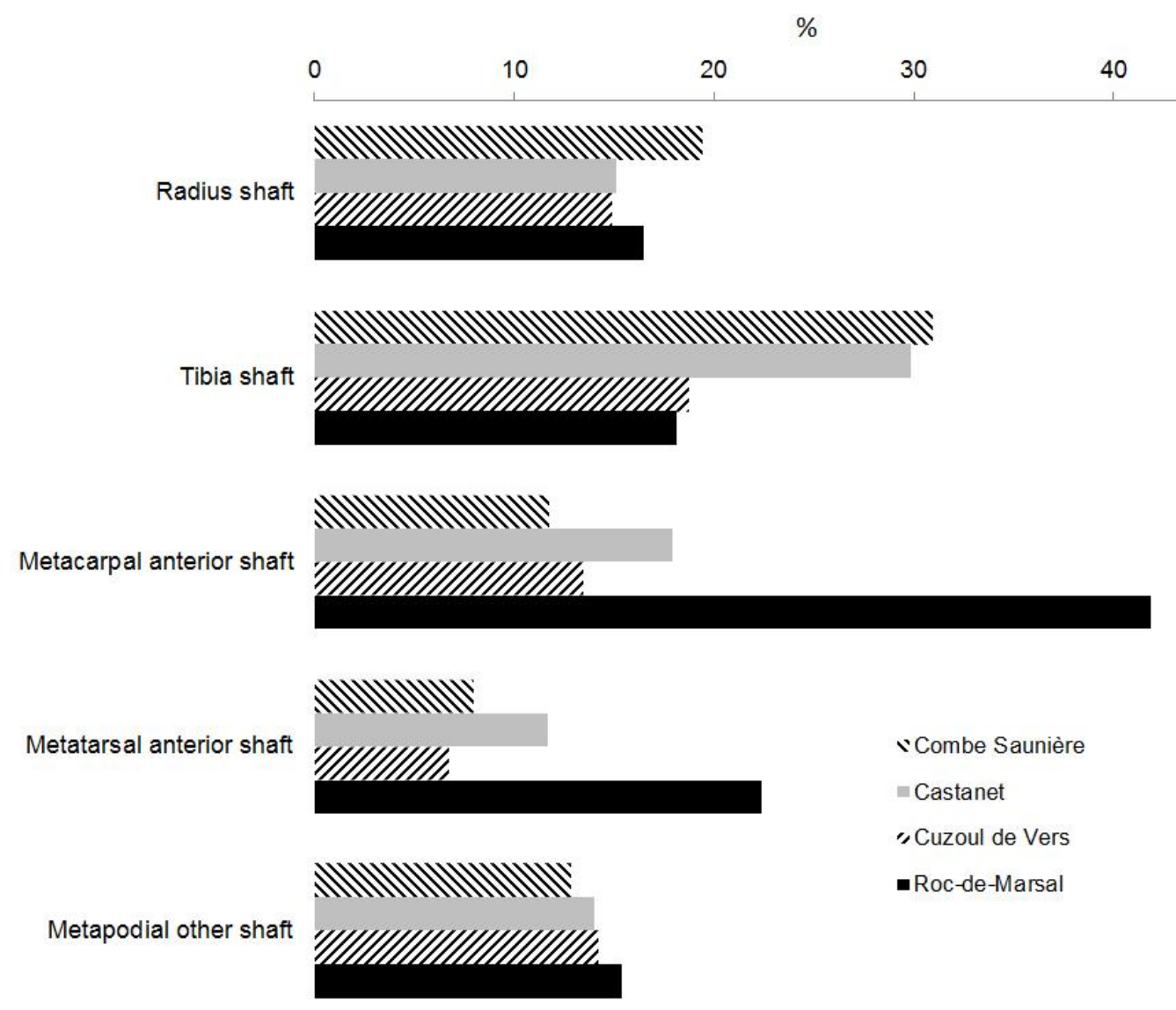




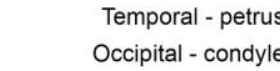

Occipital - condyle

Cranium - other fragments

Mandible

Isolated teeth

Os hyoïde

Vertebras - body

Vertebras - bridge ans articular processes Vertèbres - transverse $\&$ spinous processes

Ribs - head

Ribs - body

Girdles - articulations

Girdles - other fragments

Long bone extremities

Articulations hum., radio-u., femur \& tibia

Metapodial proximum

Metapodial distum

Long bone shafts

Patella

Basipodial

Acropodial
Roc de Marsal

layer 4

1

I

ㅁ.

ㅁ.

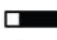

I

ป

-

a

-

I

무

[

a

I

口

마

25

50

75

$\%$ NISP
Cuzoul de Vers c. 23

without burned bones
50

25

75 


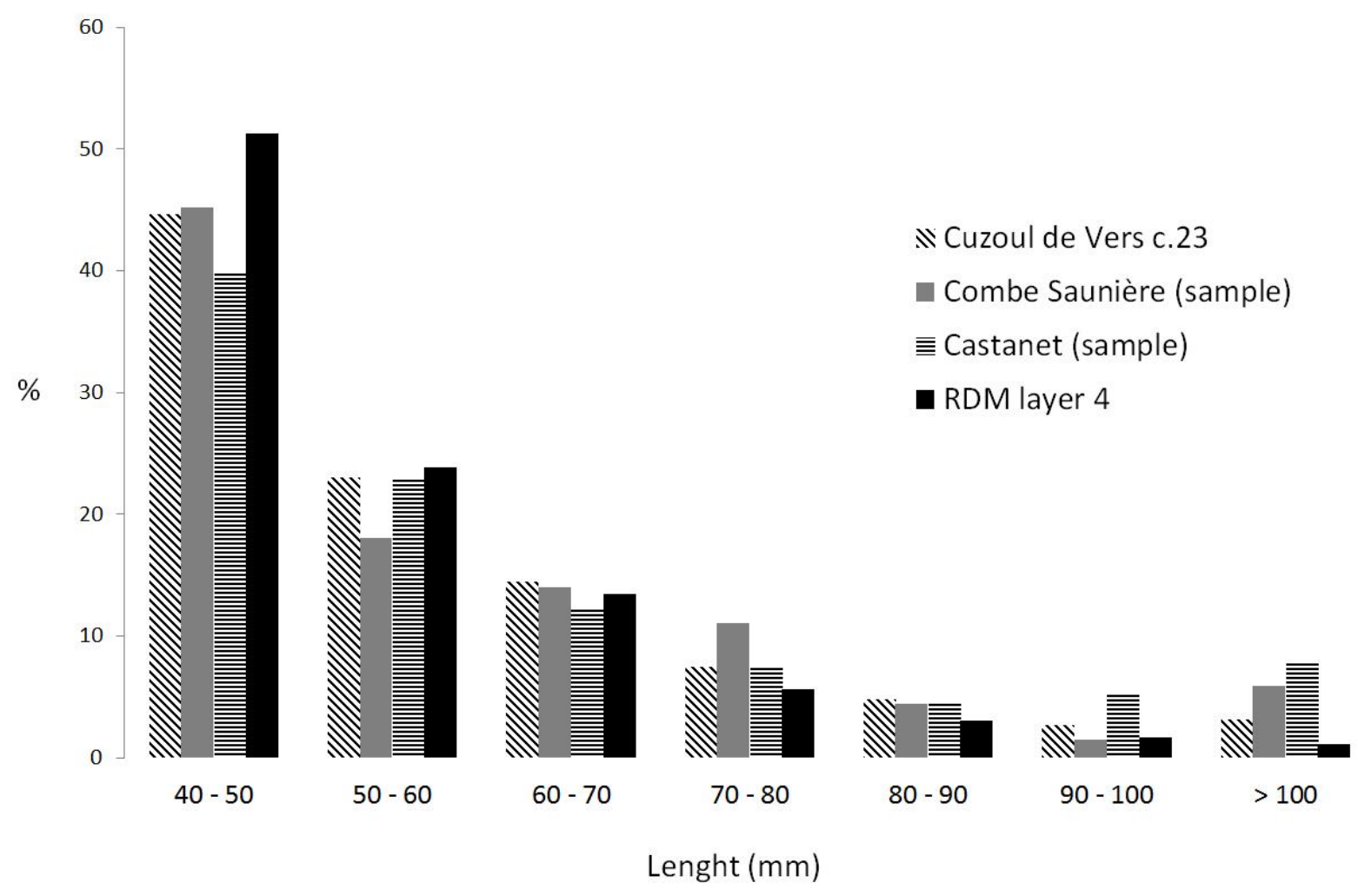




\begin{tabular}{|c|c|c|c|c|c|c|c|}
\hline $\begin{array}{c}\text { Lafille strata } \\
1953-1961\end{array}$ & $\begin{array}{l}\text { New Strata } \\
2004-2010\end{array}$ & Lithic industry & Absolute dates & $\begin{array}{l}\text { Marine } \\
\text { Isotope } \\
\text { Stages }\end{array}$ & $\begin{array}{l}\text { Volume of } \\
\text { sediment } \\
\text { (litres) }\end{array}$ & $\begin{array}{l}\text { Faunal } \\
\text { remains } \\
\text { recorded }\end{array}$ & $\begin{array}{l}\text { Lithic } \\
\text { remains } \\
\text { recorded }\end{array}$ \\
\hline XIV-XIII & 1 & Holocene/disturbed & $\mathrm{n} / \mathrm{a}$ & & 2233 & 853 & 553 \\
\hline XI-XII & 2 & \multirow{3}{*}{ Quina Mousterian } & \multirow{3}{*}{$61-45 \mathrm{ky}(\mathrm{TL})$} & \multirow{3}{*}{$\begin{array}{l}\text { end of } 4 \text { - } \\
\text { early } 3\end{array}$} & 1631 & 4503 & 988 \\
\hline $\mathrm{X}$ & 3 & & & & 182 & 1566 & 276 \\
\hline IX & 4 & & & & 1925 & 23,094 & 2969 \\
\hline \multicolumn{8}{|l|}{ VIII } \\
\hline VI-VII & 5 & \multirow{5}{*}{$\begin{array}{l}\text { High frequency of } \\
\text { Levallois and low } \\
\text { frequency of } \\
\text { retouching }\end{array}$} & & \multirow{5}{*}{4} & 532 & 5432 & 2422 \\
\hline V & 6 & & & & 154 & 1230 & 759 \\
\hline IV & 7 & & \multirow{3}{*}{$70-65$ ky (TL) } & & 504 & 3607 & 4035 \\
\hline III & 8 & & & & 511 & 2604 & 3738 \\
\hline $1-11$ & 9 & & & & 868 & 3655 & 8148 \\
\hline $\mathrm{A}$ & 10 & archaeological? & & \multirow{2}{*}{5} & 161 & 40 & 133 \\
\hline C-B & 11 to 13 & non archaeological & $87-77 \mathrm{ky}(\mathrm{TL})$ & & 98 & 37 & 25 \\
\hline
\end{tabular}


Large mammals undeterminated

Bovines

Horse

\begin{tabular}{c|c|c|c|c|c}
\hline G18 & H18 & K16 & K18 & Q17 & Total \\
\hline 147 & 34 & 209 & 72 & 7 & 469 \\
9 & 2 & 9 & 5 & & 25 \\
28 & 22 & 115 & 26 & 5 & 196 \\
\hline
\end{tabular}

Bovine to reindeer size mammals undet.

86

11

140

86

\begin{tabular}{l|l}
4 & 327
\end{tabular}

Reindeer size mammals undeterminated

Reindeer size ungulates undeterminated

Red deer

Reindeer

\begin{tabular}{|c|c|c|c|c|c|}
\hline 452 & 195 & 868 & 441 & 7 & 1963 \\
172 & 40 & 371 & & 15 & 598 \\
2 & & 4 & 3 & & 9 \\
188 & 184 & 484 & 212 & 14 & 1082 \\
\hline
\end{tabular}

Reindeer to chamois size mammals undet.

Chamois size mammals undeterminated Wolf

Chamois size ungulates undeterminated Chamois

19

15

44

16

94

\begin{tabular}{l} 
Fox size vertebrates undeterminated \\
Fox \\
Hare or Rabbit \\
Small birds \\
\hline
\end{tabular}

1

\begin{tabular}{|l|l|l|l|}
\hline 3 & 1 & & 5 \\
& & & 1 \\
1 & 1 & & 1 \\
\hline
\end{tabular}

Fox size vertebrates undeterminated Fox

Small birds
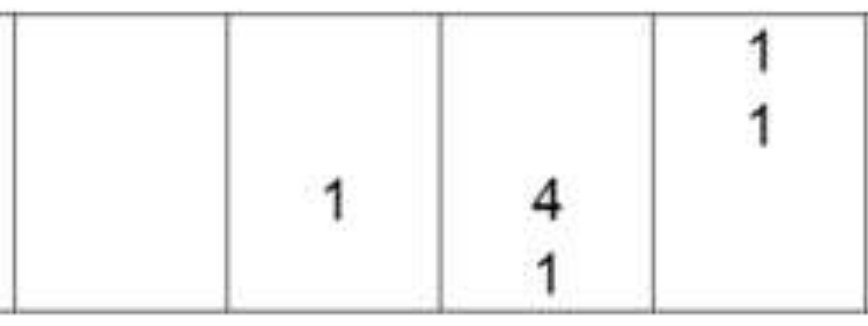

\begin{tabular}{|l|l|}
\hline & 1 \\
1 & 1 \\
& 6 \\
& 1 \\
\hline
\end{tabular}

Total 


\begin{tabular}{|l|cccccccc|}
\hline Length in $\mathrm{mm}$ & $0-10$ & $10-20$ & $20-30$ & $30-40$ & $40-50$ & $50-60$ & $60-70$ & $>70$ \\
\hline Burned & 72 & 225 & 8 & 4 & 2 & & & \\
Not burned & 2221 & 11,871 & 4274 & 1736 & 931 & 446 & 237 & 218 \\
\hline
\end{tabular}




\begin{tabular}{|l|cccc|}
\hline & NISP & Mean length & N cut & \%cut \\
\hline Cranium & 29 & 29.5 & 1 & 3.4 \\
Mandible & 43 & 47.9 & 7 & 16.3 \\
Vertebras & 21 & 32.3 & 6 & 28.6 \\
Ribs & 117 & 42.2 & 16 & 13.7 \\
Scapula & 16 & 42.7 & 3 & 18.8 \\
Coxal & 15 & 44.7 & 1 & 6.7 \\
Long bone articulations & 11 & 41.6 & 0 & 0.0 \\
Long bone shafts & 464 & 51.9 & 117 & 25.2 \\
Metapodial articulations & 13 & 39.7 & 2 & 15.4 \\
Metacarpal anterior & 43 & 45.7 & 18 & 41.9 \\
Metatarsal anterior & 135 & 48.0 & 31 & 23.0 \\
Metapodial other sides & 82 & 51.0 & 12 & 14.6 \\
Calcaneum & 9 & 35.3 & 2 & 22.2 \\
Other basipodial & 11 & 22.0 & 2 & 18.2 \\
Vestigial phalanx \& metapodial & 17 & 24.1 & 0 & 0.0 \\
Phalanx & 27 & 22.1 & 1 & 3.7 \\
Sésamoid & 13 & 15.2 & 0 & 0.0 \\
\hline
\end{tabular}

